\title{
Mapping Groundwater Potential Zones Using a Knowledge-Driven Approach and GIS Analysis
}

\author{
Qiande Zhu ${ }^{1}$ and Mohamed Abdelkareem ${ }^{2,3, *}$ \\ 1 State Key Laboratory of Hydrology and Water Resources and Hydraulic Engineering Science, Nanjing \\ Hydraulic Research Institute (NHRI), Nanjing 210029, China; qiande.zhu1@gmail.com \\ 2 Geology Department, Faculty of Science, South Valley University, Qena 83523, Egypt \\ 3 Remote Sensing Lab, South Valley University, Qena 83523, Egypt \\ * Correspondence: mohamed.abdelkareem@sci.svu.edu.eg
}

check for updates

Citation: Zhu, Q.; Abdelkareem, M. Mapping Groundwater Potential Zones Using a Knowledge-Driven Approach and GIS Analysis. Water 2021, 13, 579. https://doi.org/ 10.3390/w13050579

Academic Editor: Domenico Cicchella

Received: 17 January 2021

Accepted: 14 February 2021

Published: 24 February 2021

Publisher's Note: MDPI stays neutral with regard to jurisdictional claims in published maps and institutional affiliations.

Copyright: (c) 2021 by the authors. Licensee MDPI, Basel, Switzerland. This article is an open access article distributed under the terms and conditions of the Creative Commons Attribution (CC BY) license (https:// creativecommons.org/licenses/by/ $4.0 /)$.

\begin{abstract}
Despite the Sahara being one of the most arid regions on Earth, it has experienced rainfall conditions in the past and could hold plentiful groundwater resources. Thus, groundwater is one of the most precious water resources in this region, which suffers from water shortage due to the limited rainfall caused by climatic conditions. This article will assess the knowledge-driven techniques employed to develop a model to integrate the multicriteria derived from geologic, geomorphic, structural, seismic, hydrologic, and remotely sensed data. This model was tested on the defunct Kom Ombo area of Egypt's Nile river basin in the eastern Sahara, which covers $\sim 28,200 \mathrm{~km}^{2}$, to reveal the promising areas of groundwater resources. To optimize the output map, we updated the model by adding the automated depression resulting from a fill-difference approach and seismic activity layers combined with other evidential maps, including slope, topography, geology, drainage density, lineament density, soil characteristics, rainfall, and morphometric characteristics, after assigning a weight for each using a Geographic Information System (GIS)-based knowledge-driven approach. The paleochannels and soil characteristics were visualized using Advanced Land Observing Satellite (ALOS)/Phased Array type L-band Synthetic Aperture Radar (PALSAR) data. Several hydromorphic characteristics, sinks/depressions, and sub-basin characteristics were extracted using Shuttle Radar Topography Mission (SRTM) data. The results revealed that the assessed groundwater potential zones (GPZs) can be arranged into five distinctive groups, depending on their probability for groundwater, namely very low $(6.56 \%)$, low $(22.62 \%)$, moderate $(30.75 \%)$, high $(29.71 \%)$, and very high (10.34\%). The downstream areas and Wadi Garara have very high recharge and storage potential. Interferometry Synthetic Aperture Radar (InSAR) coherence change detection (CCD) derived from Sentinel-1 data revealed a consistency between areas with high InSAR CCD (low change) that received a plausible amount of surface water and those with very low InSAR CCD values close to 0 (high change). Landsat data validated the areas that received runoff and are of high potentiality. The twenty-nine groundwater well locations overlaid on the GPZs, to assess the predicted model, indicated that about $86.17 \%$ of the wells were matched with very good to moderate potential zones.
\end{abstract}

Keywords: hydrology; GIS; modeling; radar; groundwater; arid area; Egypt

\section{Introduction}

Water is a valuable resource necessary for life and sustainable development [1]. Affording assured water resources for agricultural and domestic activities is a seemingly tough task in areas of scarce water sources and uneven rainfall distribution [2,3]. Groundwater is an important source of freshwater, utilized for sustainable development on Earth, particularly in areas with arid/hyperarid zones. A report from UNESCO [4] stated that about 2.5 billion people around the world depend merely on groundwater sources in many activities, such as domestic use and industrial and agricultural purposes [5]. The need for freshwater resources is likely to grow and, by 2030, the level of water deficiency will 
reach about 40\% globally [6]. In Egypt, irrigation with groundwater is an important source for farmers in desert fringes, a vulnerable area due to the risk of water scarcity. Although building massive water infrastructures yields significant benefits and is a priority in several regions around the world [7], the construction of the Ethiopia Dam has made the situation worse, and it may cause a significant water crisis for the downstream countries of the Nile River, as the populations are largely dependent on its water. Moreover, the demand for water resources has increased in the past few decades due to corresponding increases in population and economic and agricultural activities.

Groundwater is a hidden natural resource beneath the Earth's surface [8] that requires integrated approaches to predict and find [9-13]. Conventional field methods are often expensive and require a long time to implement. Since the advent of satellite remotely sensed images and Geographic Information Systems (GIS) procedures, developments in groundwater reconnaissance and monitoring studies $[2,11,13,14]$ have occurred in arid/hyperarid environments. Remote sensing data have provided significantly rapid, cost-effective information on the geologic, structural, and hydrologic features that have guided us to groundwater conditions and their occurrences [9-13]. Developments in data analysis techniques have also promoted imaging in progressively finer image resolutions. Radar images have provided useful information and helped in delineating structural features and stream networks, along with estimating the rainfall rate (e.g., [2,13]). GIS techniques have allowed for the combination of multi-evidential layers that have contributed to the revealing of favorable areas for groundwater recharging.

Groundwater accumulation, infiltration, and movement depend on several factors, such as lithology, recharge conditions, structures, geomorphology, climatic situations, streams, and geologic sorts. Several studies (e.g., [1,5,9,12,13,15-23]) utilized remotely sensed images/data and GIS for groundwater infiltration, recharging, and exploration, as well as the characterization of artificial recharge zones in many areas all over the world. Crucially, remotely sensed data is crucial to the characterization of hydrogeological properties and conditions in many environments. However, even in well-mapped areas, satellite images reveal lithologic units as well as geomorphologic and structural features that were not recognized via conventional approaches. These data enhance our information on hydrogeological conditions [24,25]. Knowledge-driven approaches that allowed for the weighting and classifying of evidential maps, based on prior knowledge and information on the infiltration capacity of the utilized layers, have been successfully performed in delineating groundwater potential zones $[5,13,20]$. The aforementioned studies used common evidential layers $(n=4$ to 8$)$, such as geology, lineaments, slope, drainage density, rainfall, and topography. In the present model, we selected 10 thematic layers and added two layers to the model, including seismic activities and depressions, rather than analogous previous studies.

The desert fringes of the Kom Ombo area are promising areas for land cultivation and population growth. They are distinguished by excessive water claim and pressure on existing water stores. The objectives of the present investigation are as follows: (a) to develop a model to test the ability of knowledge-driven techniques through GIS, to delineate prospective areas of groundwater resources after ranking the multicriteria; (b) to test the extracted depressions and seismic activity for groundwater potential of the present study.

\section{Study Area}

The study area is located east of the Kom Ombo area; it presently drains westward to Kom Ombo town and receives surface water from the highlands of the Red Sea in random precipitation events. The wadis are geomorphic characteristics in the eastern desert of Egypt, covering the $\sim 28,200 \mathrm{~km}^{2}$ that extends between latitudes $22^{\circ} 4^{\prime} 47.88^{\prime \prime}$ to $25^{\circ} 16^{\prime} 23.48^{\prime \prime} \mathrm{N}$ and longitudes $32^{\circ} 57^{\prime} 28.24^{\prime \prime}$ to $35^{\circ} 9^{\prime} 13^{\prime \prime} \mathrm{E}$ (Figures 1 and 2). The upper reach collects water from the basement catchment and drains to the downstream of the Nile basin, at Kom Ombo city. The district is comprised of igneous and metamorphic 
varieties to the east, and the Upper Cretaceous/Lower Tertiary succession to the west (Figure 2). The Precambrian rocks, consisting of older metamorphosed rock units, include gneisses, metasediments, metavolcanics, and serpentinites, along with metagabbro-diorites complexes [26] (Figure 2). They are intruded by older granites, younger granites, and younger volcanic rocks. The sedimentary succession comprises Nubian Sandstone that covers a wide area and overlays the basement rocks [27]. Upper Cretaceous and Paleocene rocks form the western part of the present catchment. The area is affected by the NWSE, NE-SW, NNW-SSE, and E-W faults. The N-S trend represents the alignment of the basement extension along the contact. Based on hydrologic conditions, the area is located in an arid/hyperarid zone, with little precipitation during the rainy season, much like northern African countries (Figure 1a).
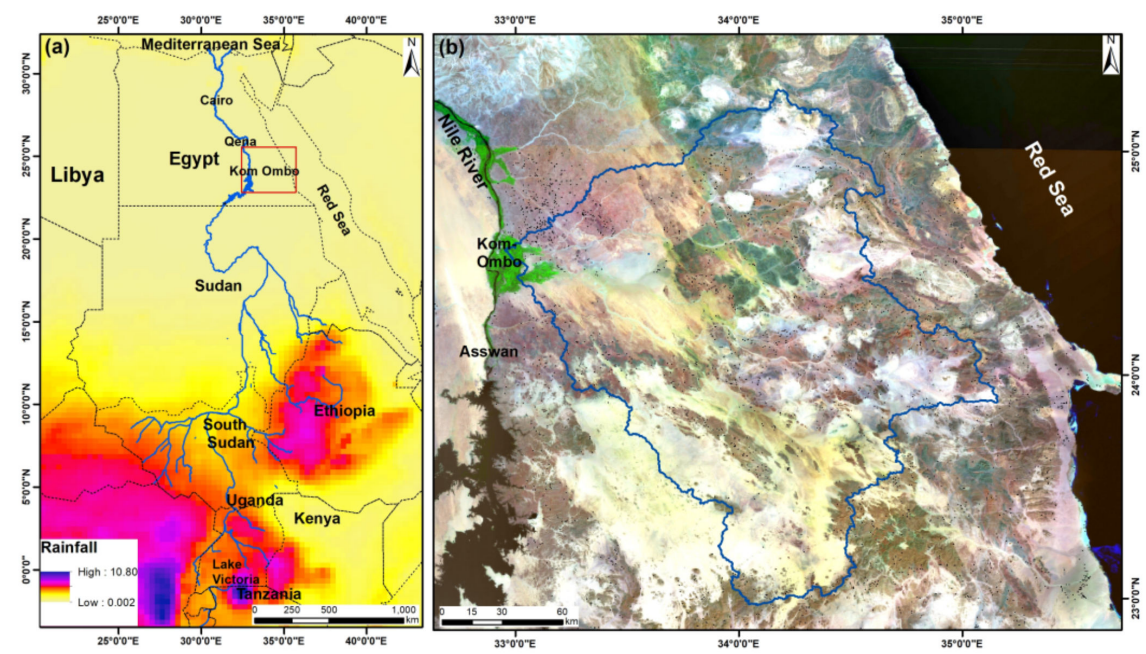

Figure 1. (a) Rainfall distribution map derived from the Tropical Rainfall Measuring Mission (TRMM) satellite covering the Nile basin, Africa (1 January 1998 to 30 November 2013); (b) Landsat-7 mosaic of the Kom Ombo area, Southern Egypt.

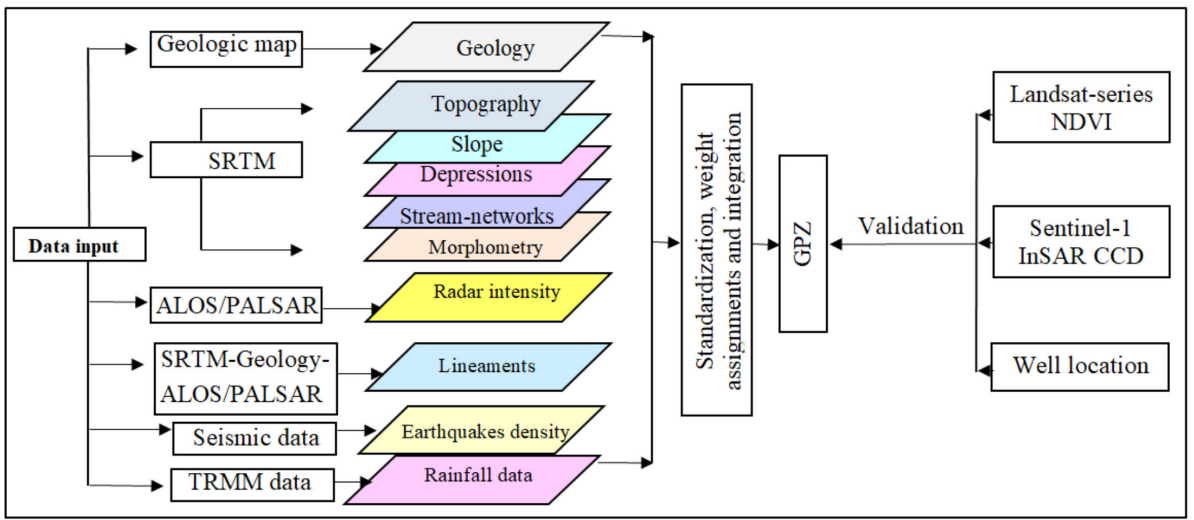

Figure 2. Flow chart showing the data and methods adopted in the present study.

\section{Data Used and Methods}

Remote-sensing data of various spatial, spectral, radiometric, and temporal resolutions have the capability to afford accurate, cost-effective, automated, near-real-time information, even in areas on the Earth that are difficult to access $[1,2,7,9]$. Technological advances in image processing and analysis have allowed for the extraction and combination of information in a fast manner that can help improve decision-making. It is a very significant approach to reveal the geologic, structural, and hydrologic conditions for better assessment, planning, and observation of water resources under any conditions [2]. 
Remote-sensing data, comprised of multispectral and radar, plays a significant role today in mapping hydrologic conditions in different climatic conditions. Multispectral remote-sensing data, comprised of information from within the visible-near-infrared and shortwave-infrared regions, utilize the land-use/cover for mapping. The data includes microwaves and visible/IR waves that are processed and integrated through the Environment for Visualizing Images (ENVI; Harris Geospatial Solutions, Broomfield, CO, USA) v5.3 and ArcGIS 10.5 software packages (ESRI Company, Redlands, CA, USA). In addition to remotely sensed data, the geological map [26] was digitized to prepare a geologic map of the present study. This integration assists in understanding the geological and structural features involved in recharging the aquifers. The data adopted for the present study are given in Figure 2.

Microwave data are significant in regional studies, such as the study of sand-buried drainages and in structural features (e.g. [28,29]). Microwave data of ALOS/PALSAR, Sentinel-1, and SRTM data are beneficial here to understand the geometry, geomorphic, and morphotectonic features. In addition to precipitation derived from TRMM records for estimating the rainfall, precipitation will be utilized in the present study between 1 January 1998 and 30 November 2013. The data were accessed from the NASA website (https:/ / giovanni.gsfc.nasa.gov / giovanni/, accessed on 10 February 2021).

The Japanese active microwave satellite sensor ALOS/PALSAR is an advanced landobserving satellite remote-sensing instrument, frequently utilized to monitor and observe the land at any time, in totally meteoric circumstances. Such a sensor employs the L-band with a spatial resolution of $25 \mathrm{~m}$ and a swath width of $70 \mathrm{~km}$; a mosaic of Jaxa "2017" was employed in this study. Although the data are available with the $\mathrm{HH}$ and $\mathrm{HV}$ polarizations, the present investigation employed the $\mathrm{HH}$ polarization.

The SRTM data are part of an international joint study conducted by National Aeronautics and Space Administration (NASA), National Geospatial-Intelligence Agency (NGA), and the Italian Space Agency (ASI) and the German Aerospace Center (Deutsches Zentrum für Luft- und Raumfahrt; DLR). Such data were used to present the topographic features of the Kom Ombo area. The data can be accessed from the United States Geological Survey (USGS) with a 30-m horizontal resolution. The digital elevation model (DEM) derived from the SRTM data was processed and visualized using GIS approaches. Stream networks were extracted by using surface flow routing constructed by the $8 \mathrm{D}$ [30], using the spatial analyst approach. The extraction of drainage and hill-shade relief is suitable for identifying the structural features controlling the terrain and groundwater aquifers. The "Fill" tool in ArcGIS v. 10.5 allowed for the defining of depressions/sinks after subtracting from the original DEM to reveal the "fill-difference". So, this can be represented in the matrix form as the original DEM layer, indicated by the "O" matrix, and the filled-DEM layer indicated by the " $F$ " matrix. Let $\mathrm{O}$ and $\mathrm{F}$ be two matrices of the same order $\left(\mathrm{m}^{*} \mathrm{n}\right)$. Let $\mathrm{O}=\left(O_{i j}\right)$ and $\mathrm{F}=\left(F_{i j}\right)$. Therefore, $(O)-(F)$ is a matrix of the same order as $\mathrm{O}$ and $\mathrm{F}$; its elements are obtained by subtracting the elements of $F$ from the corresponding elements of $O$. Then, the result matrix $\left(S_{i j}\right)$ can be estimated as follows:

$$
\left(S_{i j}\right)=\mathrm{O}-F=\left(\begin{array}{ccc}
O_{11} & \cdots & O_{1 n} \\
\vdots & \ddots & \vdots \\
O_{m 1} & \cdots & O_{m n}
\end{array}\right)-\left(\begin{array}{ccc}
F_{11} & \cdots & F_{1 n} \\
\vdots & \ddots & \vdots \\
F_{m 1} & \cdots & F_{m n}
\end{array}\right)=\left(\begin{array}{ccc}
O_{11}-F_{11} & \cdots & O_{1 n}-F_{1 n} \\
\vdots & \ddots & \vdots \\
O_{m 1}-F_{m 1} & \cdots & O_{m n}-F_{m n}
\end{array}\right) .
$$

Two scenes of Sentinel-1 were acquired on 19 September 2020 and 18 September 2018. VV polarizations were utilized to characterize an image, revealing the changes in land features. The phase and intensity data of the single look complex (SLC) SAR format were used to characterize the coherence change detection (CCD) information and define the activities of the active streams and surface land features [31]. The InSAR CCD has revealed land surface changes and activities in the spatiotemporal span [31,32]. In this method, every pixel of a SAR includes intensity and phase information. Mathematically, 
the interferometric coherence $(G)$ of the two SAR scenes can be computed as in [33] (Equation (2)).

$$
\gamma \cong \frac{\left|\sum_{i=1}^{L} \sum_{j=1}^{M} S c_{1}\left(x_{i}, z_{j}\right) S c_{2}^{*}\left(x_{i}, z_{j}\right)\right|}{\sqrt{\sum_{i=1}^{L} \sum_{j=1}^{M}\left|S c_{1}\left(x_{i}, z_{j}\right)\right|^{2} \sum_{i=1}^{L} \sum_{j=1}^{M}\left|S c_{2}\left(x_{i}, z_{j}\right)\right|^{2}}},
$$

where $S c 1$ and $S c 2$ are the complex signals of the "master" and "slave" scenes. The means of the kernels with $\mathrm{L} \times \mathrm{M}$ pixels can be used to estimate the coherence of an output pixel [31]. The result of the coherence ( $\mathrm{v}$ ) map extends from 0 , for complete change, to 1 , which defines no change [34].

The Landsat Operational Land Imager (OLI) optical sensor with 9 spectral bands carried by Landsat-8 was launched on 11 February 2013. Two scenes of Level 1 (path/row 174/042 and path/row 174/043) OLI data were acquired on 9 September 2020. The obtained scenes were mosaicked and linked to the coordinate system of UTM Zone 36N. The OLI bands 2, 3, 4, 5, 6, and 7 were utilized here to conduct image transformation and enhancement techniques. The data were radiometrically calibrated using ENVI v.5.3. A scene of a Landsat-7 Enhanced Thematic Mapper (ETM+) image, acquired on 21 January 2010, was also used to visualize the flood event in 2010 over the study area. To monitor the changes in vegetation, the Normalized Difference Vegetation Index (NDVI) was carried out using Landsat series, Landsat-OLI (8 September 2020), Landsat ETM+ (10 September 2000), and Landsat-5 (15 November 1986) of the same area covered by path/row 174/043.

The GIS technique was used for analyzing the different spatial data by applying various logical conditions. Lineaments were derived from high-resolution imagery by digitization using the GIS technique and analyzed using Rockworks-16 software to extract the rose diagram. The geological map was digitized using a map from [26], prepared from a thematic layer of geology. Spatial modeling of prospecting groundwater potential zones (GPZs) using multicriteria was applied using knowledge-driven techniques.

The knowledge-driven predictive overlay model $[35,36]$ was applied using a geographic information system (GIS). This model is based on known data, and the relative importance of each observation is decided on by the user. The GIS approach uses the raster overlay, in which each pixel of each layer has the same geographic location. This makes the overlay process more appropriate for integrating characteristics for several data sets into an output layer. The numeric values given for each layer promote the mathematical combination process and give a new grade to each pixel in the output cell. The weighted values are then given to the spatial predictor maps and their categories.

Based on the knowledge-driven technique of combining multicriteria [37], the scores of each evidential map are assigned to different maps and their intermap features. In this model, the evidential maps are weighted from 1 to 4 and the given weight was normalized to control the occurrence and infiltrate the groundwater. The intermap feature classes were also assigned weights and normalized in every evidential map. The GPZ, which represents the weighted average of the combined data-based maps [37], can be delineated using the following equation:

$$
G P Z=\sum_{i=1}^{n} W i \times F i
$$

where Wi refers to the evidential layer weight and Fi corresponds to the weight of the intermap class.

\section{Results}

GIS-based approaches, remotely sensed data, and supplementary geologic-geomorphic models were merged to delineate potential areas of plausible water resources of the selected area in Egypt. A knowledge-based method to combine the multicriteria of several factors (e.g., geology/geomorphology, topography, slope, lineaments, depression, seismic activity, drainage density, rainfall, and alluvial deposits) was derived from remotely sensed data, as 
the existence, infiltration, accumulation, and movements of groundwater are controlled by the aforementioned parameters that serve as inputs to the thematic layers.

The information resulting from the remotely sensed data and geologic-geomorphic features can be integrated with the GIS technique to find the GPZ using Equation (2). Groundwater cannot be perceived directly from the Earth's surface, so a variety of approaches are required to provide information regarding its potential occurrence and characteristics. Such sources of water are necessary because of their clear color and the absence of pathogenic organisms and turbidity. Furthermore, their stable chemical composition and storage capacity are significant.

\subsection{Geology/Geomorphology}

Lithologic characteristics are significant, as the infiltration of the precipitated water to the groundwater aquifer is governed by the porosity and permeability of the surface layer $[1,5]$. Based on processing and interpretation of the remotely sensed data, the area of east Kom Ombo consists of different rock units. The crystalline rocks occupy the eastern part of the present study. The Cretaceous/Tertiary succession occupies the western part of the present study. The basement rocks, sedimentary succession, Nubian sandstone, and Quaternary deposits cover about $51.23,0.87,34.20$, and $13.68 \%$ of the study area, respectively. The wadi bed built-up of sand and gravel deposits increases the porosity, which is a good factor for groundwater recharging [38], versus the basement rocks comprised of impermeable rocks of granitoids, metavolcanics, and serpentinites (Figure 3). The abundance of sand deposits related to the sandstone exposures in the study area support the long-term goal of infiltration capacity in the basin, controlled by structural features. Based on the geologic map, the evidential geologic layer is categorized into four classes (Table 1): the higher (8) are the favorable areas for groundwater infiltration vs. the lowest (1); (Figure 3b).

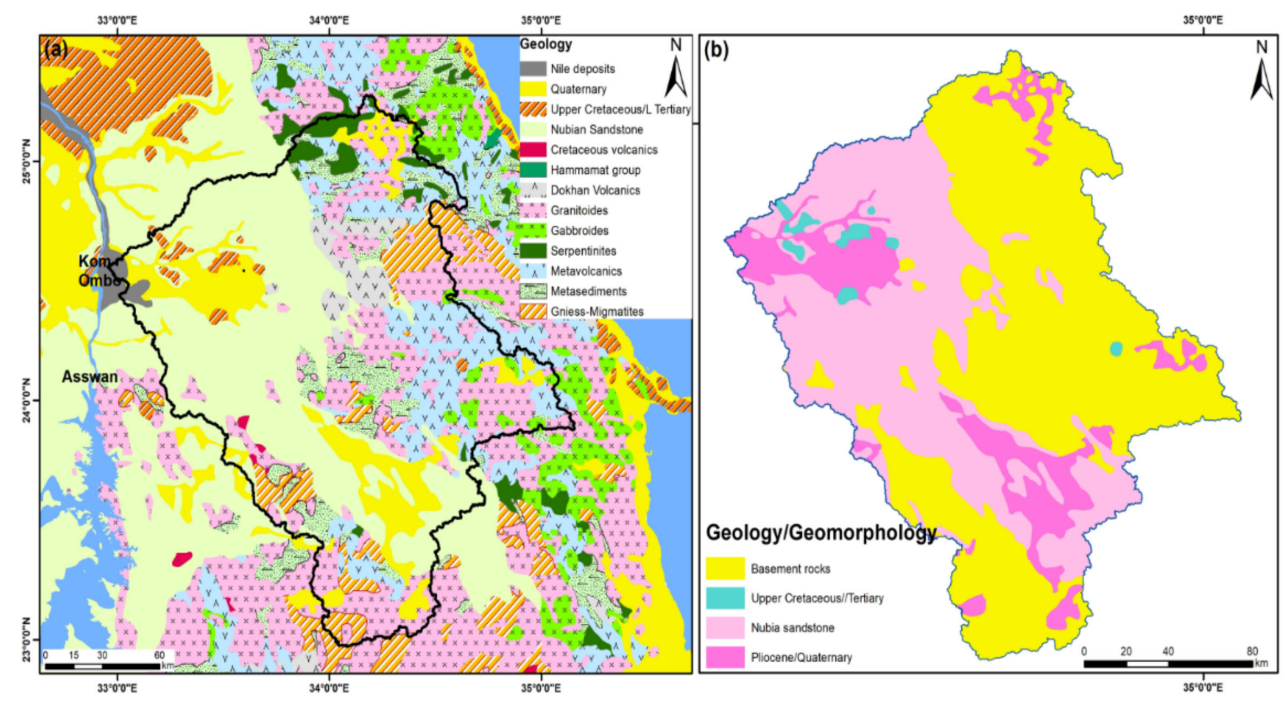

Figure 3. (a) Geologic map [26] of the studied area of east Kom Ombo; (b) simplified geologic density map. 
Table 1. Thematic map weight and capability value of the thematic maps.

\begin{tabular}{|c|c|c|c|c|c|c|c|}
\hline Thematic Layer & Rank & $\begin{array}{l}\text { Normalized Layer } \\
\text { Weight (Wi) }\end{array}$ & Detailed Features/Subclasses & Subclass & Rank & $\begin{array}{c}\text { Capability Value (CVi) } \\
\text { (Feature Normalized Weight) }\end{array}$ & Area $(\%)$ \\
\hline \multirow{4}{*}{ Lithology } & \multirow{4}{*}{5} & \multirow{4}{*}{$(0.125)$} & Quaternary deposits & High & 4 & 0.4 & 13.68 \\
\hline & & & Nubian Sandstone & Moderate & 3 & 0.3 & 34.20 \\
\hline & & & Upper Cretaceous/L-Tertiary & Low & 2 & 0.2 & 0.87 \\
\hline & & & Basement rocks & Very low & 1 & 0.1 & 51.23 \\
\hline \multirow{4}{*}{ Topography } & \multirow{4}{*}{4} & \multirow{4}{*}{$(0.1)$} & $91-280$ & Very high & 5 & 0.33 & 17.90 \\
\hline & & & $399-517$ & Moderate & 3 & 0.20 & 31.85 \\
\hline & & & $517-744$ & Low & 2 & 0.13 & 11.70 \\
\hline & & & $744-1710$ & Very low & 1 & 0.07 & 1.50 \\
\hline \multirow{4}{*}{ Slope } & \multirow{4}{*}{4} & \multirow{4}{*}{$(0.1)$} & 0-2.46 (nearly level) & Very high & 5 & 0.33 & 62.15 \\
\hline & & & 2.46-5.71 (gently sloping) & High & 4 & 0.27 & 24.48 \\
\hline & & & 5.71-11.06 (moderately sloping) & Moderate & 3 & 0.20 & 8.84 \\
\hline & & & $19.65-50.84$ (steep-very steep) & Very low & 1 & 0.07 & 1.18 \\
\hline \multirow{4}{*}{$\begin{array}{c}\text { Sinks/ } \\
\text { Depressions }\end{array}$} & \multirow{4}{*}{7} & \multirow{4}{*}{$(0.175)$} & -82 to -8 & Very high & 8 & 0.44 & 0.906 \\
\hline & & & -7.99 to -5 & Moderate & 6 & 0.33 & 1.73 \\
\hline & & & -4.99 to -2 & Low & 3 & 0.17 & 6.36 \\
\hline & & & -1.99 to 0 & Very low & 1 & 0.06 & 91.00 \\
\hline \multirow{5}{*}{ Stream-networks } & \multirow{5}{*}{5} & \multirow{5}{*}{$(0.125)$} & $58.73-83.74$ & Very high & 5 & 0.33 & 7.48 \\
\hline & & & $48.80-58.37$ & High & 4 & 0.27 & 76.17 \\
\hline & & & $40.51-48.80$ & Moderate & 3 & 0.20 & 35.43 \\
\hline & & & $29.52-40.51$ & Low & 2 & 0.13 & 22.89 \\
\hline & & & $5.14-29.52$ & Very low & 1 & 0.07 & 8.03 \\
\hline
\end{tabular}


Table 1. Cont.

\begin{tabular}{|c|c|c|c|c|c|c|c|}
\hline Thematic Layer & Rank & $\begin{array}{l}\text { Normalized Layer } \\
\text { Weight (Wi) }\end{array}$ & Detailed Features/Subclasses & Subclass & Rank & $\begin{array}{c}\text { Capability Value (CVi) } \\
\text { (Feature Normalized Weight) }\end{array}$ & Area $(\%)$ \\
\hline \multirow{5}{*}{ Runoff } & \multirow{5}{*}{2} & \multirow{5}{*}{0.05} & $25.02-29.57$ & Very high & 5 & 0.33 & 30.23 \\
\hline & & & $29.57-35.70$ & High & 4 & 0.27 & 9.57 \\
\hline & & & $35.70-37.03$ & Moderate & 3 & 0.20 & 28.87 \\
\hline & & & $37.03-39.71$ & Low & 2 & 0.13 & 8.66 \\
\hline & & & $39.7-49.71$ & Very low & 1 & 0.07 & 22.67 \\
\hline \multirow{4}{*}{ Radar intensity } & \multirow{4}{*}{4} & \multirow{4}{*}{$(0.1)$} & $26.98-55.47$ & High & 4 & 0.27 & 27.36 \\
\hline & & & $55.47-112.43$ & Moderate & 3 & 0.20 & 27.50 \\
\hline & & & $112.43-164.06$ & Low & 2 & 0.13 & 11 \\
\hline & & & $164.06-255$ & Very low & 1 & 0.07 & 7.25 \\
\hline \multirow{4}{*}{ Lineaments } & \multirow{4}{*}{4} & \multirow{4}{*}{$(0.1)$} & $51-79$ & Very high & 5 & 0.33 & 0.963 \\
\hline & & & $32-50$ & High & 4 & 0.27 & 12.74 \\
\hline & & & $13-21$ & Low & 2 & 0.13 & 35.40 \\
\hline & & & $0-12$ & Very low & 1 & 0.07 & 23.97 \\
\hline \multirow{4}{*}{ Rainfall } & \multirow{4}{*}{3} & \multirow{4}{*}{$(0.075)$} & $0.238-0.04248$ & High & 4 & 0.4 & 4.77 \\
\hline & & & $0.017317-0.023818$ & Moderate & 3 & 0.3 & 9.99 \\
\hline & & & $0.0126213-0.017317$ & Low & 2 & 0.2 & 36.44 \\
\hline & & & $0.00579-0.012613$ & Very low & 1 & 0.1 & 49.09 \\
\hline \multirow{3}{*}{ Earthquakes } & \multirow{3}{*}{2} & \multirow{3}{*}{0.05} & $431.7-1251.08$ & High & 3 & 0.5 & 1.36 \\
\hline & & & $93.21-431.74$ & Low & 2 & 0.3 & 29.92 \\
\hline & & & $0-93.2$ & Very low & 1 & 0.2 & 68.71 \\
\hline
\end{tabular}




\subsection{Topography}

The topography layer is an important layer that governs the direction of water flow over the land; it also controls the occurrence of groundwater and recharge potential [12,13]. The wadi is surrounded by elevated hills and the main catchment is the Red Sea Highlands. In this image, the low topographic areas collect, hold, and store much more water than the high topographic areas during the rainfall season. The low altitudes yield water recharge and movement. The DEM of the study area was acquired from the SRTM data (Figure 4a). Analysis of the SRTM DEMs data revealed that the land-surface height of the area varies from $91 \mathrm{~m}$ to $1710 \mathrm{~m}$. The topographic values revealed high runoff in an east-west direction. The area of high elevation occupies the eastern, northern, and southern parts of the studied basins. Interpretation of the DEM data revealed a network of fracture systems consistent with the structural elements that were probably incised in the plateau. Based on the infiltration capabilities, the elevations were sorted into five groups based on their tendency of water storing (Figure $4 \mathrm{~b}$ ). The areas of very low, low, moderate, high, and very high topography cover about $1.50,11.70,31.85,37$, and $17.90 \%$ of the area, respectively (Table 1 ). The low-topography areas promote water accumulation and infiltration capabilities.

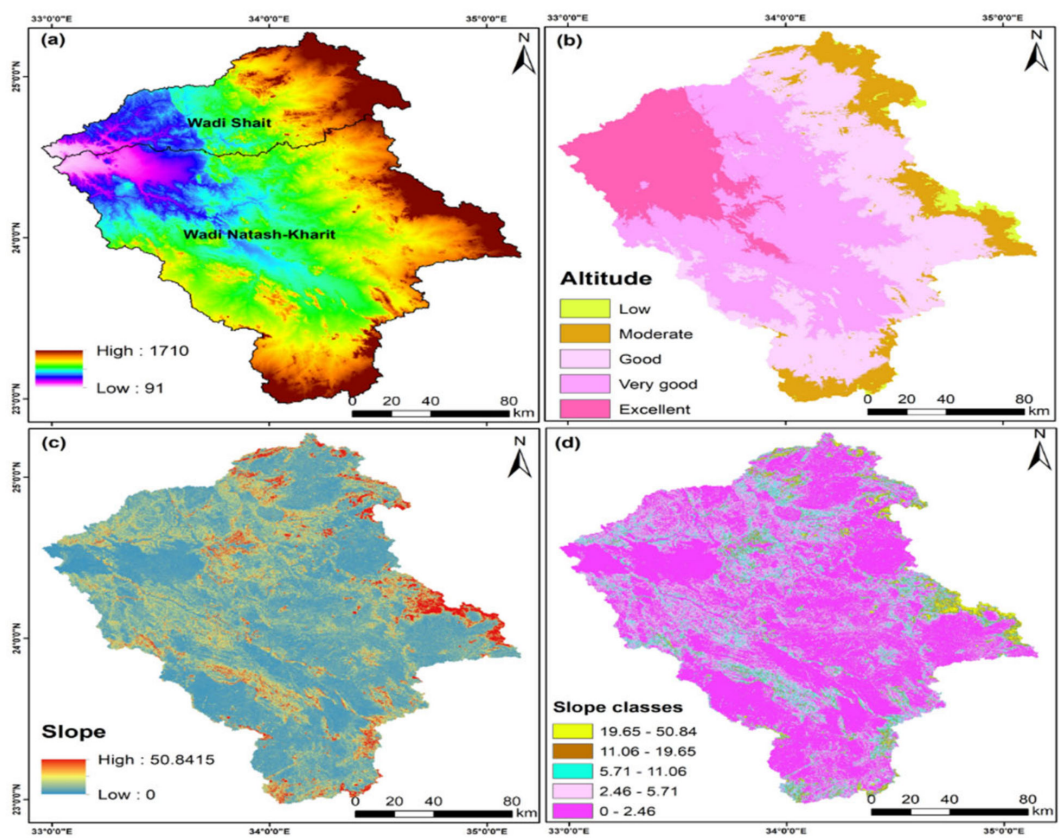

Figure 4. Topography maps: (a) SRTM DEM data; (b) topography density map; (c) slope map; (d) slope density map.

\subsection{Slope}

The slope is likely to affect the water flow, occurrence, movement, and infiltration capacity of groundwater $[19,39]$. The slope has an inverse relationship with the infiltration of the surface water to the aquifers underneath $[13,40]$. The slope can often be influenced by the rock types, rate of erosion, climate conditions, and tectonic activities. The slope map is derived by the SRTM DEM. It varies between $0^{\circ}$ and $50.84^{\circ}$ (Figure $4 \mathrm{c}$ ) and is grouped into five classes. The low slope degree (flat areas) considers a promising area of surface water infiltration and recharge potential; thus, it is given a high rank, as the slope controls the runoff and vertical infiltration of precipitation [19]. However, steep-slope areas are assigned a low rank and high runoff capacity [9]. The slope direction reflects the dominant westward runoff to the Nile Valley. Based on the slope degree map, the majority of the area $(\sim 65 \%)$ extends under the gentle slope $\left(<5^{\circ}\right)$ surface level that represents the suitable zones for recharging capability (Figure $4 \mathrm{~d}$ ), which allow for a holding time for surface water infiltration (Table 1). The very high potential degree (5), high (4), moderate (3), low (2), and 
very low (1) slope cover about $62.15,24.48,8.84,3.33$, and $1.18 \%$ of the studied basin area, respectively (Figure $4 \mathrm{~d}$ ).

\subsection{Depressions/Sinks}

Depressions are low surface elevations that must be filled with water until the water elevation reaches a level at which the flow would pour out of the depression. Using the Fill tool in ArcMap v. 10.5, the depressions/sinks were filled to their spill elevation (Figure 5). Subsequently, the "fill-difference" could be calculated by subtracting the initial DEM from the filled-DEM. This allowed for the generation of a raster that signified the depth of the depressions in the original surface [41]. These depressions capture the flow of water, which is accumulated and stored until it infiltrates into the aquifers underneath. In arid regions, such a process can happen during rainy storms. The results of the extracted depression layers are classified into four categories: -82 to -8 (high), -7.99 to -5 (moderate), -4.99 to -2 (low), and -1.99 to 0 (very low), based on the capability of long-term capturing and storing of accumulated water (Figure 6a). The implementation of such data would benefit the GPZ model. The plausible promise area of groundwater infiltration covers about $0.90 \%$ of the entire area (Table 1). A large number of depressions were revealed along the streambed channels. These depressions are most likely consistent with specific areas (e.g., upstream of W. Beizah, a tributary of W. Shait (Figure 6b)) that most likely carved the sandstone, and are low-topography-controlled by faults along $\mathrm{W}$. Shait (Figure $6 c, d$ ), behind the natural barriers or stream-neck at W. Garara (Figure $6 \mathrm{e}, \mathrm{f})$. The extracted depressions are validated using the analogous areas in Landsat-8, ALOS/PALSAR, and the DEM (Figure $6 \mathrm{~g}-\mathrm{i}$ ), to understand the uncertainties. The results of validation revealed more than $82 \%$ of accuracy.
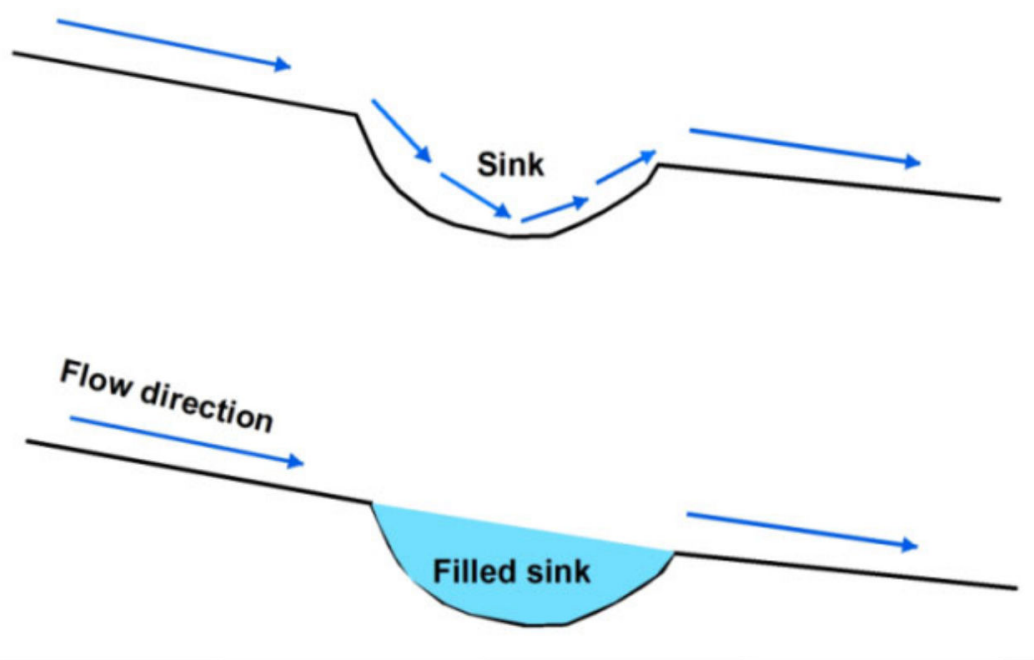

Figure 5. Illustration of the relationship between flow direction and depressions. 


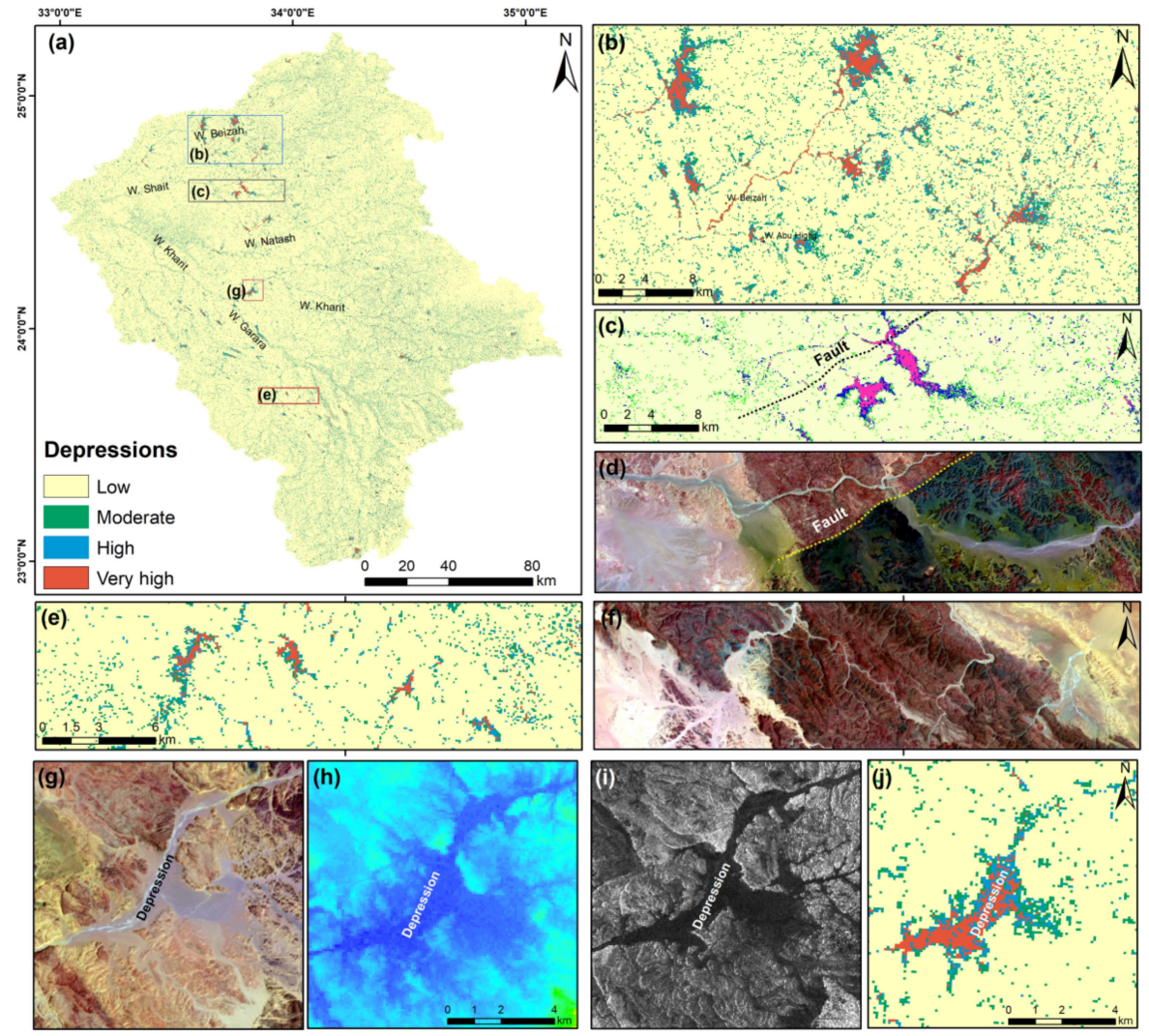

Figure 6. Fill-difference depressions. (a) Depressions and sinks of the studied basins; (b) depressions derived from fill-difference of W. Beizah, a tributary of W. Shait; (c,d) fill-difference depression behind fault line; (e,f) depression at W. Garara; (g-j) Landsat, SRTM, ALOS/PALSAR, respectively, which matched to the fill-difference depression.

\subsection{Stream-Networks}

The nature of the stream-networks and catchment area control the harvesting of the precipitation on the highly elevated areas (Figure 7). Catchments that capture excessive amounts of rainfall have the capability to infiltrate and recharge the groundwater aquifers. Several studies have revealed that stream-network density is inversely connected to the rate of recharge processes (e.g., [5,42]), but others $[2,23,40,43]$ have indicated that the high drainage density reveals a high infiltration capability because of the highly dissected land surface. The results of using the D8 method and stream networks were predicted in the DEM. In this article, we related the areas of high density (Figure 7a,b) to having greater suitability for recharging and infiltration capacity. As the majority of the area is a gentle slope, the areas with high drainage density are influenced by high groundwater and low runoff [23]. Therefore, the studied basins can be graded into five categories: 5.14-29.52 (very low), 29.52-40.51 (low), 40.51-48.80 (moderate), 48.80-58.73 (high), and 58.73-83.74 (very high) $\mathrm{km} / \mathrm{km}^{2}$ (Table 1 ). The plausible areas of high groundwater recharging cover $7.48 \%$ of the area. 


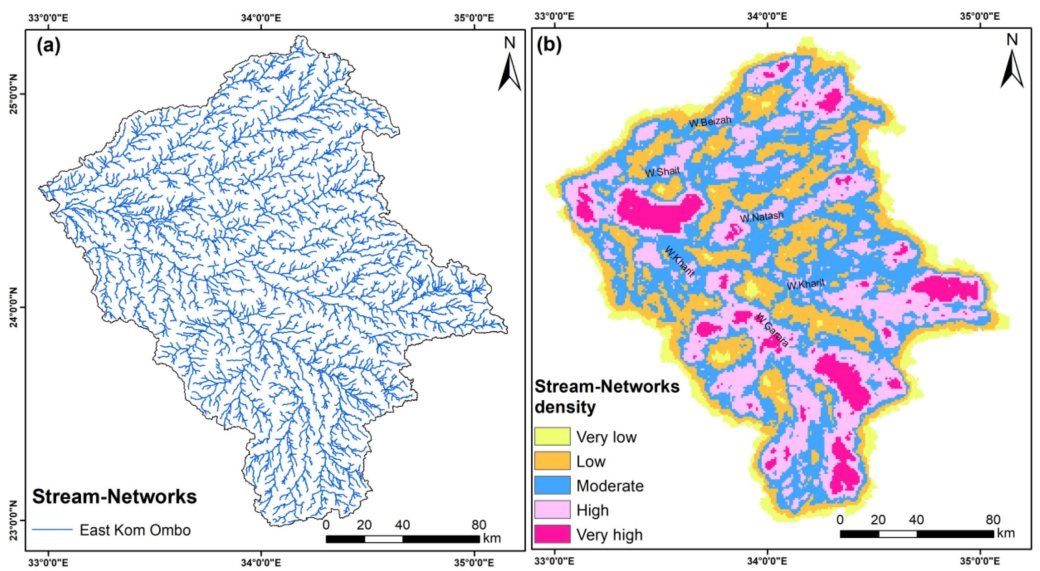

Figure 7. (a) Automatically derived stream-networks of the studied basins; (b) stream density map.

\subsection{Morphometric Characteristics (Runoff)}

Based on morphometric analysis, the perimeter $(\mathrm{P})$ of the studied basin is $1537 \mathrm{~km}$, with a bounded area (A) of about $28,200 \mathrm{~km}^{2}$. The wadi was subdivided into 11 sub-basins (Tables 2 and 3; Figure 8). The expressed formula used in the morphometric analysis of the studied basins is referenced in Table. 2 [24]. The A of the delineated 11 sub-catchments varies from 678 to $8632 \mathrm{~km}^{2}$. Several parameters were calculated to characterize the prominent expanses of runoff (Table 2), using the linear equations referenced in [24]. Using such equations, the summation of the runoff rate of the sub-basins ranges from 25.02 (low runoff) to 49.71 (high runoff), categorized into five ranks that extend from the lowest to the highest (5). Based on that, the runoff was found to be inversely related to the infiltration capability and the runoff potential map (Figure $8 \mathrm{~b}$ ) was rearranged to infiltration capacity (Figure $8 \mathrm{c}$ ). The potential areas of infiltration reach $30 \%$ of the study area (Table 1 ).

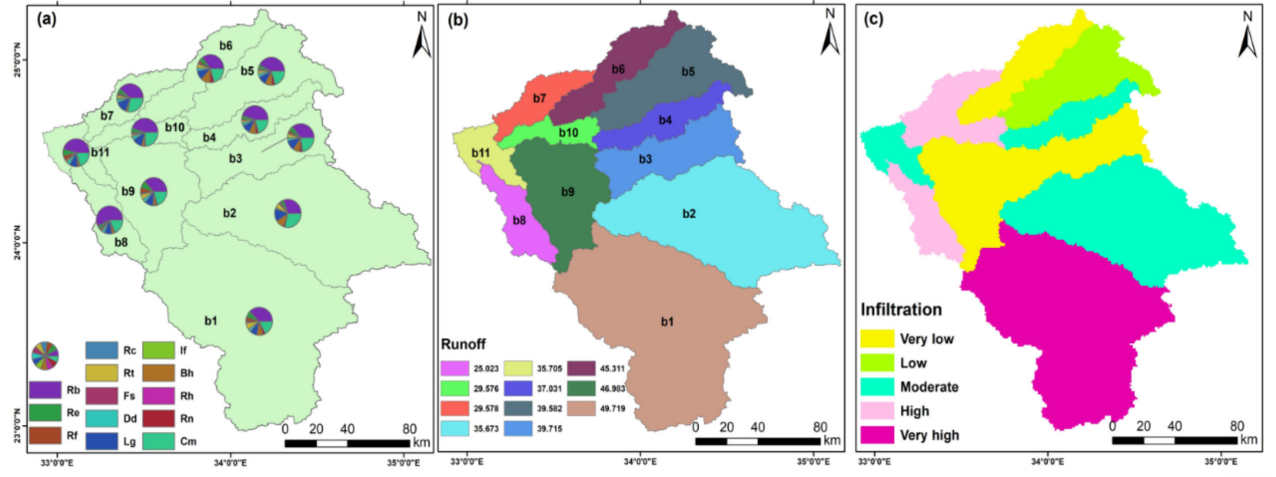

Figure 8. Morphometric analysis of studied basins: (a) distribution of the morphometric parameters in the studied sub-basins; (b) runoff potential map; (c) infiltration potential map. 
Table 2. Morphometric parameters of the study area.

\begin{tabular}{|c|c|c|c|c|c|c|c|c|c|c|c|c|c|c|c|c|c|c|}
\hline \multirow[b]{2}{*}{ Basin_NO } & \multicolumn{4}{|c|}{ Drainage } & \multicolumn{8}{|c|}{ Basin Geometry } & \multicolumn{3}{|c|}{ Drainage Texture } & \multicolumn{3}{|c|}{ Relief Characteristics } \\
\hline & $\mathbf{U}$ & $\mathrm{Nu}$ & $\begin{array}{c}\mathbf{L u} \\
(\mathbf{k m})\end{array}$ & $\mathbf{R b}$ & $\underset{\left(\mathrm{km}^{2}\right)}{A}$ & $\mathbf{P}(\mathbf{k m})$ & $\mathbf{L b}$ & $\mathbf{R f}$ & $\operatorname{Re}$ & Rt & Rc & Fs & Dd & If & Lg & Bh & $\mathbf{R h}$ & $\mathbf{R n}$ \\
\hline 1 & 6 & 789 & 3812.494 & 4.852 & 8632.454 & 783.309 & 110.542 & 0.706 & 0.948 & 1.007 & 0.177 & 0.091 & 0.442 & 0.040 & 1.132 & 0.917 & 0.008 & 0.405 \\
\hline 2 & 5 & 583 & 2654.584 & 4.728 & 6201.148 & 642.403 & 146.962 & 0.287 & 0.605 & 0.908 & 0.189 & 0.094 & 0.222 & 0.021 & 2.250 & 1.489 & 0.010 & 0.331 \\
\hline 3 & 5 & 202 & 858.150 & 3.728 & 2065.566 & 458.404 & 83.668 & 0.295 & 0.613 & 0.441 & 0.124 & 0.098 & 0.415 & 0.041 & 1.203 & 0.836 & 0.010 & 0.347 \\
\hline 4 & 4 & 123 & 494.358 & 5.263 & 1198.548 & 373.799 & 81.333 & 0.181 & 0.480 & 0.329 & 0.108 & 0.103 & 0.412 & 0.042 & 1.212 & 0.934 & 0.011 & 0.385 \\
\hline 5 & 5 & 238 & 1061.780 & 3.919 & 2451.637 & 485.397 & 90.293 & 0.301 & 0.619 & 0.490 & 0.131 & 0.097 & 0.433 & 0.042 & 1.154 & 1.244 & 0.014 & 0.539 \\
\hline 6 & 4 & 169 & 698.795 & 4.750 & 1602.815 & 407.931 & 99.911 & 0.161 & 0.452 & 0.414 & 0.121 & 0.105 & 0.436 & 0.046 & 1.147 & 0.965 & 0.010 & 0.421 \\
\hline 7 & 4 & 95 & 373.053 & 3.684 & 984.171 & 298.645 & 72.078 & 0.189 & 0.491 & 0.318 & 0.139 & 0.097 & 0.379 & 0.037 & 1.319 & 0.248 & 0.003 & 0.094 \\
\hline 8 & 4 & 82 & 442.687 & 7.667 & 1057.470 & 304.204 & 76.888 & 0.179 & 0.477 & 0.270 & 0.144 & 0.078 & 0.419 & 0.032 & 1.194 & 0.408 & 0.005 & 0.171 \\
\hline 9 & 5 & 276 & 1269.512 & 3.934 & 2763.974 & 431.642 & 63.744 & 0.680 & 0.931 & 0.639 & 0.186 & 0.100 & 0.459 & 0.046 & 1.089 & 0.400 & 0.006 & 0.184 \\
\hline 10 & 4 & 64 & 280.441 & 4.545 & 678.213 & 272.578 & 60.438 & 0.186 & 0.486 & 0.235 & 0.115 & 0.094 & 0.414 & 0.039 & 1.209 & 0.336 & 0.006 & 0.139 \\
\hline 11 & 4 & 70 & 370.717 & 5.000 & 816.389 & 275.334 & 37.557 & 0.579 & 0.858 & 0.254 & 0.135 & 0.086 & 0.454 & 0.039 & 1.101 & 0.242 & 0.006 & 0.110 \\
\hline Kom & & & & & & & & & & & & & & & & & & \\
\hline $\begin{array}{l}\text { Ombo } \\
\text { Basins }\end{array}$ & 6 & 2674 & 12316.567 & 4.869 & 28452.402 & 1536.954 & 241.677 & 0.487 & 0.788 & 1.740 & 0.151 & 0.094 & 0.433 & 0.041 & 1.155 & 1.633 & 0.007 & 0.707 \\
\hline
\end{tabular}

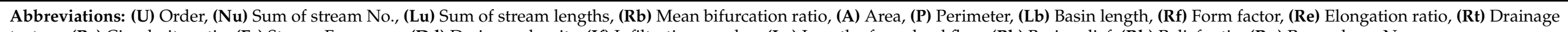
texture, (Rc) Circularity ratio, (Fs) Stream Frequency, (Dd) Drainage density, (If) Infiltration number, (Lg) Length of overland flow, (Bh) Basin relief, (Rh) Relief ratio, (Rn) Ruggedness No.

Table 3. The computed runoff degree from morphometric parameters.

\begin{tabular}{|c|c|c|c|c|c|c|c|c|c|c|c|c|c|}
\hline Basin_NO & $\mathbf{R b}$ & $\mathbf{R f}$ & $\operatorname{Re}$ & $\mathbf{R t}$ & Rc & Fs & Dd & If & Lg & Bh & $\mathbf{R h}$ & $\mathbf{R n}$ & $\begin{array}{c}\Sigma \text { of } \\
\text { Runoff }\end{array}$ \\
\hline 1 & 3.828 & 5.000 & 5.000 & 5.000 & 4.406 & 2.987 & 4.702 & 4.106 & 4.850 & 3.165 & 2.879 & 3.797 & 49.719 \\
\hline 2 & 3.951 & 1.927 & 2.229 & 4.484 & 5.000 & 3.362 & 1.000 & 1.000 & 1.000 & 5.000 & 3.589 & 3.131 & 35.673 \\
\hline 4 & 3.414 & 1.151 & 1.227 & 1.488 & 1.000 & 4.596 & 4.210 & 4.419 & 4.574 & 3.220 & 4.112 & 3.619 & 37.031 \\
\hline 5 & 4.764 & 2.027 & 2.343 & 2.323 & 2.134 & 3.801 & 4.558 & 4.374 & 4.773 & 4.214 & 5.000 & 5.000 & 45.311 \\
\hline 6 & 3.930 & 1.000 & 1.000 & 1.929 & 1.654 & 5.000 & 4.606 & 5.000 & 4.799 & 3.319 & 3.406 & 3.938 & 39.582 \\
\hline 7 & 5.000 & 1.212 & 1.314 & 1.431 & 2.524 & 3.722 & 3.646 & 3.504 & 4.206 & 1.019 & 1.000 & 1.000 & 29.578 \\
\hline 9 & 4.749 & $\begin{array}{l}1.107 \\
4.808\end{array}$ & 4.857 & 3.095 & 4.881 & 4.199 & 5.000 & 4.983 & 5.000 & 1.507 & 2.097 & 1.807 & 46.983 \\
\hline 10 & 4.135 & 1.184 & 1.275 & 1.000 & 1.341 & 3.412 & 4.227 & 3.891 & 4.585 & 1.302 & 1.820 & 1.404 & 29.576 \\
\hline 11 & 3.678 & 4.065 & 4.275 & 1.101 & 2.359 & 2.176 & 4.912 & 3.878 & 4.957 & 1.000 & 2.162 & 1.143 & 35.705 \\
\hline
\end{tabular}




\subsection{Radar Intensity}

The ALOS/PALSAR data covering the study area (Figure 9a) reveal the variation in the backscatter characteristics of the soil and bedrock units. Such radar intensity data show the nature of the deposits in the study basin, which are observed with difficulty in the Landsat data [43]. The fine deposits depicted in radar data reveal fine sediments and alluvial sand sediments. The coarse-grained texture reveals bedrocks that demonstrate massive characteristics. This is because of the low, diffuse backscattered beams. The wadi bed has backscattered fine deposits. A fused ALOS/PALSAR and Landsat- 8 discriminated the geologic and structural features (Figure $9 \mathrm{~b}$ ) and vegetated areas in the downstream, along with patches within the sedimentary rocks (Figure 9c). Discrimination of the fine deposits from the bedrocks and coarse-grained deposits was conducted using the logical operation (classification) of ArcGIS tools. Based on this operation, the fine deposits occupy the majority of the wadi bed and stream areas on the bed rocks of the study area.

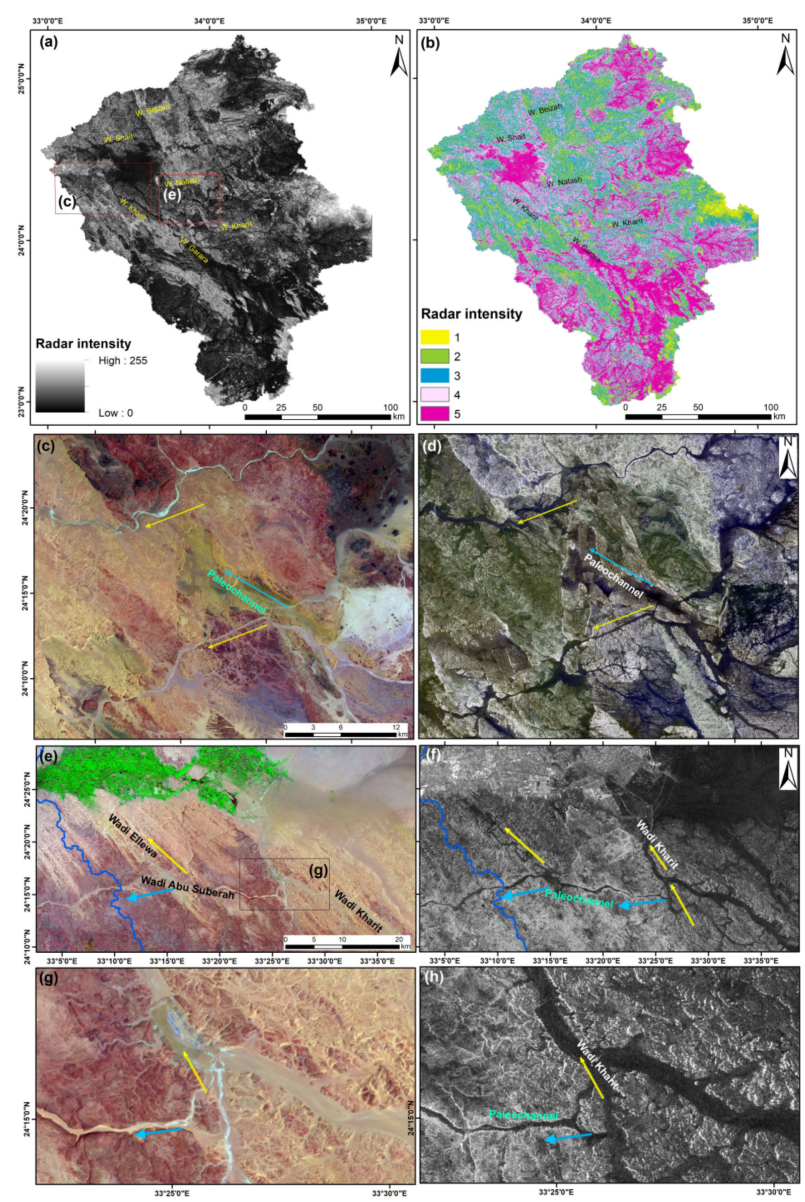

Figure 9. (a) ALOS/PALSAR of the study area; (b) radar density map of the physical properties of the soil using ALOS/PALSAR data; (c) Landsat- 8 of downstream of W. Kharit. Yellow arrows reveal the present westward flow and the past NW outlet, as shown in the cyan arrow, that are revealed by a fused ALOS/PALSAR and Landsat-8 image in $(\mathbf{d}) ;(\mathbf{e}, \mathbf{f})$ downstream area of W. Kharit showing the SW flow that was captured by the NW flow, as depicted by the yellow arrow (present flow) and cyan arrow (past flow) in (g,h).

The dry sand of the wadi deposits, derived mainly from sandstone, provides optimum conditions for the used L-band to penetrate deeply, because of its transparency in radar images. These sand deposits revealed an alluvial origin caused by the erosion of the surrounding rocks. Several fractures were probably hidden throughout these deposits and connected to the groundwater aquifer. ALOS/PALSAR data revealed several areas of dark color representing fine sediments or areas rich in sand deposits; this is because 
the low backscattered signal, compared to the rough surface, spreads in many directions, and we know a diffuse reflection results in a bright tone on the surface. The radar map was categorized into 5 grades of categories ranging from 1 (low backscattered) to 5 (high backscattered). The results from the radar map revealed that the high values indicate locations for low groundwater recharging and the low values displayed the high GPZs (Figure $9 \mathrm{~b}$ ), which reach $26.85 \%$ of the entire area (Table 1 ).

The active (ephemeral) streams during rainfall storms have a spectrally bright view compared to the surrounding pixels of Landsat-8 images (see Figure 9c). A fused ALOS/ PALSAR and Landsat-8 (Figure 9d) system probes the sand cover and shows a near-surface view of the paleochannel (cyan arrow) that was drained under sand and is barely visible in the Landsat-8 images (Figure 9c). These images revealed that the NW flow (cyan arrow) was captured by the present SW. However, in the downstream area of W. Kharit, the SW flow is captured by the NW flow (Figure 9e,f), such as Wadi Abu Suberah [44]. The filling wadi deposits appear dark in the ALOS/PALSAR images, versus the intermediate to bright outcrops of surface bedrocks reflecting textural information based on surface roughness (e.g. $[9,45,46]$. The radar and optical data also provide evidence of the stream capture process of Wadi Abu Suberah (west) by Wadi Kharit to the northwest, resulting from active tectonic movements (Figure 9g,h).

\subsection{Lineaments}

Lineaments are the linear or curved geologic structural features (faults/fractures/joints) that play a significant factor in characterizing the promising areas for groundwater potential. Recently, several studies have focused on using structural features in recognizing groundwater possibilities and explained the role of fracture systems prospecting the availability of groundwater resources (e.g., $[9,12,15,47])$. Such investigations revealed that groundwater potential is positively related to areas of higher lineament intensity, where using structural features controls the aquifer system, as the damaged zones of faults can be represented by channels or blocks to the flow of the groundwater $[48,49]$. The permeability along the fault planes is delimited by the faulted rock and time of the fracture/fault systems [49]. The faults have a tendency to be occupied with broken or crushed material (fault gouge) of high permeability that facilitates water movement (e.g., [2,50]).

The fracture/fault zones connected to the aquifers are also noteworthy. Optical/ remotely sensed images provided evidence of such a connection (Figure 10a). Lineaments were extracted using remote sensing data, such as the shaded relief map derived from SRTM data, fused ALOS/PALSAR and Landsat-8, stream-networks, and Landsat-8 (Figure 10a). Integration of lineaments [26] and shaded relief of DEM data allowed for the preparation of the lineaments map (Figure 10b).

The E-W trend captured the NW-SE trend caused by the tectonic activities of the Red Sea. A fused ALOS/PALSAR and OLI image allowed for the visualization of the geomorphic features and structural continuity (Figure 10c) of W. Garara. This image highlighted the geologic structures and fault system control of the drainage system along the basement rocks. The structural types and movements guided the formation of the porous and permeable zone for possible recharging processes and controlling groundwater flow. The area under exploration was modified by tectonics in the Miocene, which allowed for the breaking of the plateau, contemporaneous with the Red Sea events. Moreover, high-resolution data revealed that several fracture/fault zones control the granitoids of the Arabian-Nubian Shield (Figure 10b).

The lineaments are dominated NW-SE in the extension of the Arabian-Nubian Shield crossing the main wadi channel that rends NE-SW (Figure 10a). The fused images (Figure 10d,f) improved the form of the lineaments' visualization, rather than using individual images of Landsat (Figure 10c,e). The lineaments' density map was grouped into five numerical categories (5 (highest), 4 (high), 3 (moderate), 2 (low), and 1 (lowest); Figure $10 \mathrm{~b}$ ), covering about $23.97,35.40,26.91,12.74$, and $0.963 \%$ of the study area, respectively 
(Table 1). These five categories depend on their relative recharging properties. The area of intense density is a promising site for groundwater penetration and recharging comparable to the low-density zone. The rose diagram revealed the major trends, including the NW and SE directions that affect the area; however, NE-SW faults are less abundant. The NW-SE and sub-E-W dominate the basement rocks, and the NW-SE characterize the sedimentary rocks of the area. Noteworthily, fused ALOS/PALSAR and OLI data successfully visualize the structurally controlled paleochannels that are difficult to recognize from OLI data alone (Figure $10 \mathrm{~g}, \mathrm{~h}$ ).
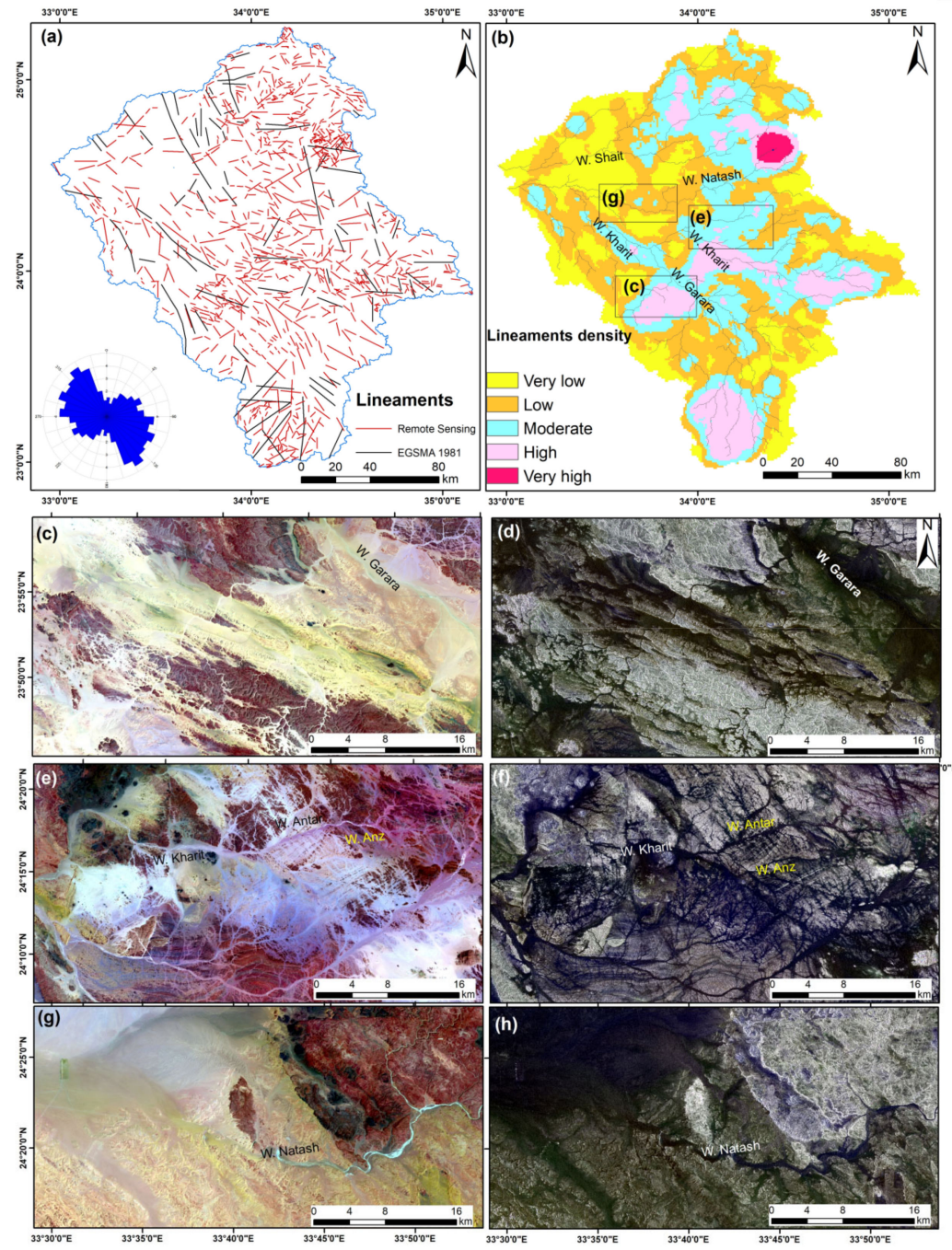

Figure 10. (a) Lineaments derived from remotely sensed data and a geological map [26]; (b) lineament density map; (c) Landsat-8 image of W. Gara; (d) a fused ALOS/PALSAR and Landsat- 8 of the same area as in (c), the NW-SE trend is cut by the NE-SW trend; (e,f) highly altered and dissected crystalline rocks of Kharit upstream; (g,h) paleochannels of the downstream of W. Natash that are difficult to reveal in Landsat-8 in (g) are revealed in a fused ALOS/PALSAR and Landsat-8 (h).

\subsection{Rainfall Data (TRMM)}

Rainfall is a crucial factor of the hydrological characteristics of a region, as it is the source of runoff and surface water during storms [5]. The average of the rainfall intensity data (mm/day) derived from the TRMM satellite covering the study area (years 19972015) provides important precipitation information on the conditions and anomalies of precipitation in different areas (Figure 11a). This data estimates the runoff of surface water and excessive rainfall in the catchments. The excessive rainfall intensities allow for a high recharge capability to the groundwater aquifer, as infiltration depends on the intensity 
and duration of precipitation. The low value of precipitation reveals the low recharge of the precipitated water to groundwater aquifers. Subsequently, the rainfall data was sorted into four numerical categories (Table 1). These categories (Figure 11b) range from 1 (low) to 4 (high). The results of the precipitation anomalies map explained that the low class of rainfall intensities indicate a lower possibility of infiltration characteristics and recharging groundwater, and the high class displays a high probability of the infiltration and recharging process (Figure $11 \mathrm{~b}$ ). The potential areas of the rainfall precipitation cover $4.77 \%$ of the study area, mostly consisting of the downstream and upstream areas. During storms, the precipitated water collected and contributed to runoff on the streams (Figure 11c,d), so the W. Shait received a high amount of precipitation during storms on 17-18 January 2010, which was validated by a bright cyan spectral signature in the band composite 7, 4, and 2 of Landsat-7 (Figure 11e,f). Therefore, these streams that receive precipitation would hold groundwater, as the majority of surface water can infiltrate the sediments below.

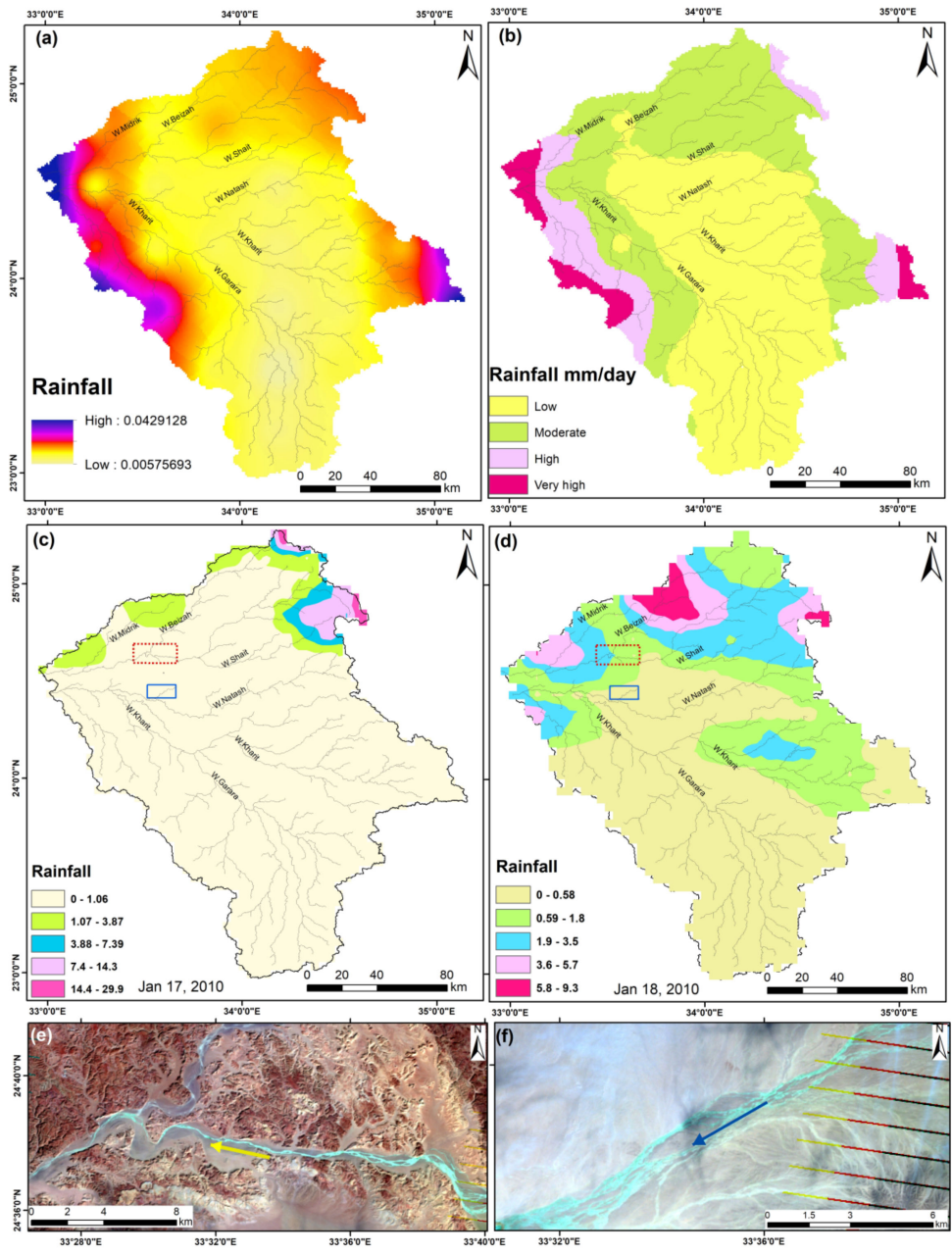

Figure 11. (a) Average rainfall (years 1997-2015) in the study area; (b) rainfall density map; (c,d) rainfall storm on 17 to 18 January 2010; (e,f) evidence of surface water signature of the downstream of W. Shait, as revealed from Landsat-7, acquired on 25 January 2010.

\subsection{Earthquake (Seismicity)}

Earthquakes are natural processes that can yield rupturing and deformations in the Earth's crust. In this work, we assume that the deformation of the brittle rocks yields the opening of fractures/fault systems [51] and changes in the bulk permeability and porosity $[52,53]$. Therefore, areas frequently subjected to earthquakes are probably dominated by ruptures reaching the subsurface aquifers (Figure 12). The response of the groundwa- 
ter recharge/discharge processes driven by the occurrence of the fracture/fault systems caused by earthquakes causes an enhancement of permeability by widening fractures [54]. Therefore, areas with low earthquake intensity reveal the low recharge/discharge processes versus areas of high seismicity. The magnitudes of these earthquakes range from 0.1 to 3.9, according to the record of the National Research Institute of Astronomy and Geophysics (NRIAG). The seismic activity density map of the study area ranges between zero and 1251 (Figure 12b). Thus, the seismic instability map was categorized into 3 rank classifications, ranging from 1 (low density) to 3 (high density). The areas of high intensity cover about $1.36 \%$ of the study area and promote groundwater infiltration characteristics (Table 1).

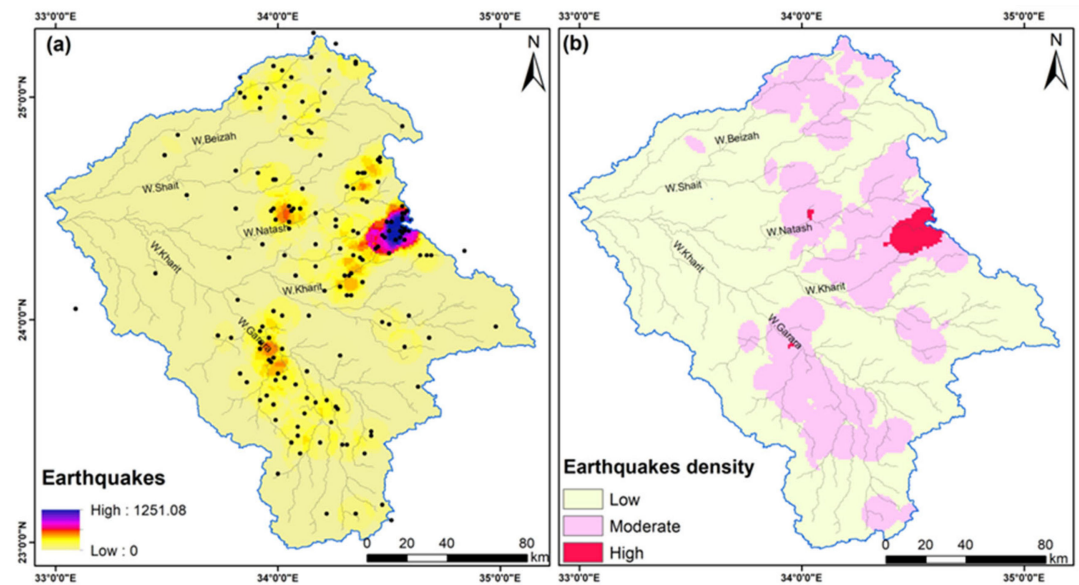

Figure 12. Earthquake data: (a) distribution of earthquakes locations; (b) density of earthquakes.

\section{Groundwater Prospect Map}

To understand where groundwater recharge is, several evidential maps were compiled, as water infiltration to the aquifers is controlled by geologic and hydrologic factors and landuse/cover factors. The ten (10) evidential maps are geology/geomorphology, topography, slope, depressions/sinks, stream-networks, runoff, radar backscattered, lineaments, rainfall data, and earthquakes. Figure 13 describes the GPZ map that is quantitatively categorized into several zones of analogous sorts. The delineated recharge sectors are termed very low, low, moderate, high, and very high, involving areas of about $6.56,22.62,30.75,29.71$, and $10.34 \%$, respectively (Figure 13a; Table 4 ). The spatial variations of the very high to high zones cover the downstream areas and fit areas of high wadi deposits on the main streams. This area consists of porous, thick sediments and a low topography, is highly fractured, and contains depressions with a flat to gentle slope, promoting the increase of water infiltration and recharging beneath aquifers that could reveal the groundwater prospectively.

Table 4. GPZs of the present study.

\begin{tabular}{|c|c|c|c|c|}
\hline & GPZs & Weight & Area & Wells \\
\hline 1 & Very high & $39-72$ & $10.34 \%$ & \multirow{2}{*}{$\begin{array}{c}n=13 \\
(44.83 \%)\end{array}$} \\
\hline 2 & High & $72-86$ & $29.71 \%$ & \\
\hline 3 & Moderate & $86-97$ & $30.75 \%$ & $n=12(41.38 \%)$ \\
\hline 4 & Low & $97-110$ & $22.62 \%$ & \multirow{2}{*}{$n=4(13.79 \%)$} \\
\hline 5 & Very low & $110-487$ & $6.56 \%$ & \\
\hline
\end{tabular}




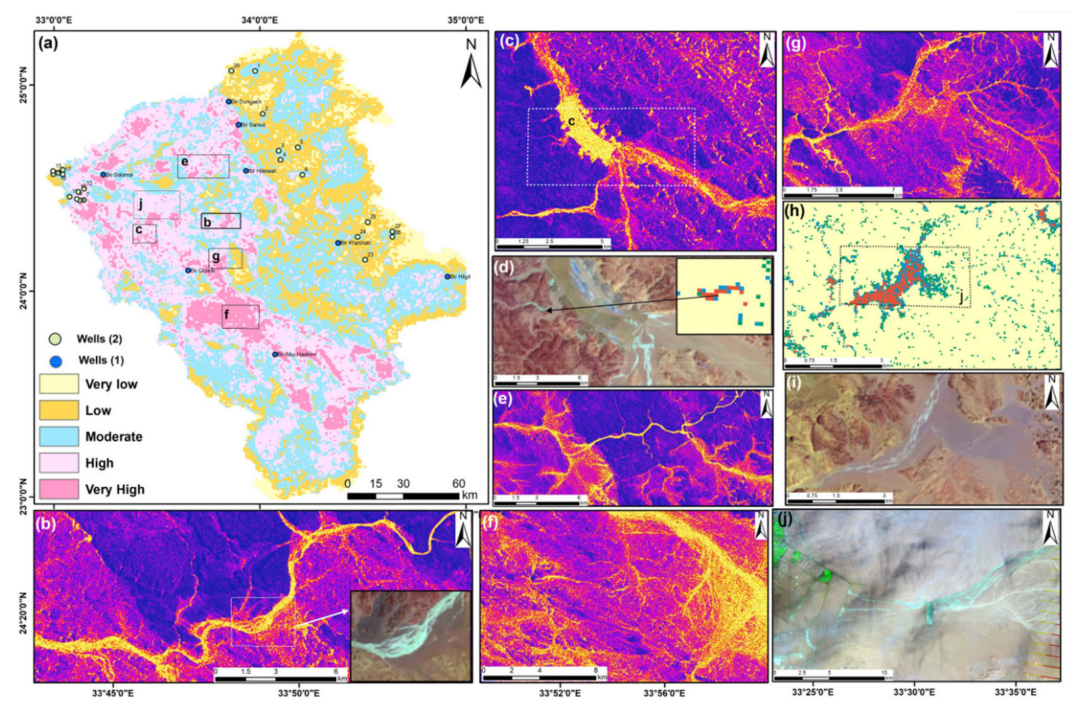

Figure 13. (a) Groundwater recharge potential map overlaid by water wells, quoted from [55] (Well 1) and [56] (Well 2); (b) subset of InSAR coherence map reveals the change in land-cover along wadis as a result of runoff, and Landsat-8 images reveal agricultural activities; (c,d) InSAR CCD image provides evidence of water accumulation as indicated by the Landsat image in (d) following the rainfall storm, which is consistent with the active stream (yellow); (e) InSAR CCD reveals active streams of W. Shait that receive runoff during storms as well as (f) W. Garara; $(\mathbf{g}, \mathbf{h})$ InSAR CCD image reveals changes along the mainstream that are consistent with the extracted depression. Landsat image in (i) depicts the existence of an active stream in bright tone. (j) Evidence of water accumulation downstream of W. Natash.

The twenty-nine well locations that were overlaid on the GPZs to assess the predicted model indicated that about 13,12, and 4 wells are consistent with the very high to high, moderate, and low potential zones, respectively (Table 4 ). About $86.17 \%$ of the wells are matched with the very good to moderate potential zones. The well data located in the eastern side belong to the fractured Precambrian aquifer.

The InSAR coherence map reveals the change in the land-cover along wadis as a result of the runoff of active streams during rainy storms. Landsat- 8 reveals agricultural activities. The InSAR CCD image (Figure 13c,g,e) provides evidence of water accumulation, as indicated by the Landsat image in panel (d), following the rainfall storm, which is consistent with the active stream marked in yellow. Most of these active streams are most likely holding much water in some ponds (Figure 13c,d) and are consistent with areas of low topography (Figure 13h,i). The basement areas that consist of igneous and metamorphic rocks, particularly in the eastern section of the area, are illustrated by absent vegetation with a low porosity and high topography, with a steep slope that aids the demarcation of poor recharging zones. Remarkably, the evidence of surface water is also detected in the Landsat image (Figure 13j) acquired on 21 January 2010, following a rainy storm (17-18 January 2010), which also matched the rainfall data in Figure 11c,d.

\section{Discussion}

Based on the analysis of the optical/radar remotely sensed data, the study area is comprised of crystalline rocks to the east and Phanerozoic sorts to west, which represent the main catchment, and are predominantly affected by NW-SE and E-W lineaments of the fracture/fault systems. Such fault systems could have controlled the groundwater movements and infiltration capacity [50]. Wadis east of Kom Ombo probably experienced intense past hydrological processes, revealed in the denudation of the Cretaceous/Tertiary succession $[9,25]$. Radar data support that these were affected by E-W lineaments. Abu Subeirah is captured by the NW-SE trend of W. Kharit (Figure 9e-h), due to structural activities in the Kom Ombo area. 
Crucially, the present defunct wadi east of Kom Ombo has been an active stream during the past pluvial conditions, like the rest of Egypt's wadis $[24,57,58]$. Such conditions were likely predominant during the Late Tertiary period or later $[9,59]$ and experienced structural activities related to Red Sea tectonics. This is judged by the existence of paleochannels and the fact that the position of the Equator at that time was more north (most likely at the present-day latitudes of Sudan and Chad) than its current latitude. Such a geometry would have allowed heavy precipitation over Egypt [60] and aided in the removal of the wide part of the Upper Cretaceous/Lower Tertiary succession to the south, as noticed in the Kom Ombo area. Importantly, the exposed Nubian Sandstone covers a wide area of the basin, and such deposits promote surface water infiltration to the groundwater aquifers and are more suitable for storing groundwater [61].

Today, the discontinuous rainfall showers on the Red Sea highlands, as the main catchment, yield surface water flow and water accumulation in ponds, as depicted by the Landsat and InSAR CCD images that allow for the recharging of groundwater aquifers. The Red Sea highlands are the most elevated section of the study area and are comprised of crystalline rocks. Such runoff recharges the aquifers underneath, as evidenced by the existence of surface water during storms.

Groundwater data analysis [56] revealed that the water wells to the east (Figure 13a) that annually recharge, mainly from rainfall, are consistent with fractured and weathered Precambrian aquifers, and their depths range from 3.8 to $31.5 \mathrm{~m}$. The water wells are consistent with zones of high-very high groundwater potential to the west, and are most likely consistent with Quaternary aquifers comprised of sand and gravel, with a thickness from 40 to $120 \mathrm{~m}$ and depths ranging from 2 to $8.4 \mathrm{~m}$. This aquifer recharges mainly from the Nile and the surface runoff resulting from the precipitation, as the hydraulic activity of the middle part of the present study is $\sim 80 \mathrm{~m} /$ day [62].

Based on our analysis of Landsat data, the majority of the downstream area is cultivated using water resources from surface- and groundwater. The existence of the highly vegetated areas led to the existence of the surface- and groundwater and appropriate soil properties that allow for infiltration capability [63]. The areas of agricultural activities are considered the promising areas for groundwater recharge capacity [64], but bare areas of impermeable rocks are recognized as having low recharge capacity [6].

The InSAR CCD image revealed that the highly changed areas are consistent with the CCD image, with low values $(\sim 0)$ that matched the vegetated areas and active streams (Figure 14a,b). The signature of the water is in cyan color in Landsat images (Figure 14c-e). Applying the vegetation index NDVI $=(\mathrm{NIR}-\mathrm{R}) /(\mathrm{NIR}+\mathrm{R})$ to the Landsat data, a series of years $(1986,2000$, and 2020) revealed major changes in vegetation, covering areas of 86 , 159 , and $342 \mathrm{~km}^{2}$, respectively (Figure 14c-h). From 1986 to 2000 to 2020, land reclamation increased eastward (Figure 14). The output of the NDVI values extends from -1 to +1 ; the areas of maximum vegetation land-cover are close to +1 . The expansion of agriculture is very extensive, and the presence of the surface water of the Nile and groundwater allowed for the cultivation of the majority of the downstream area. 

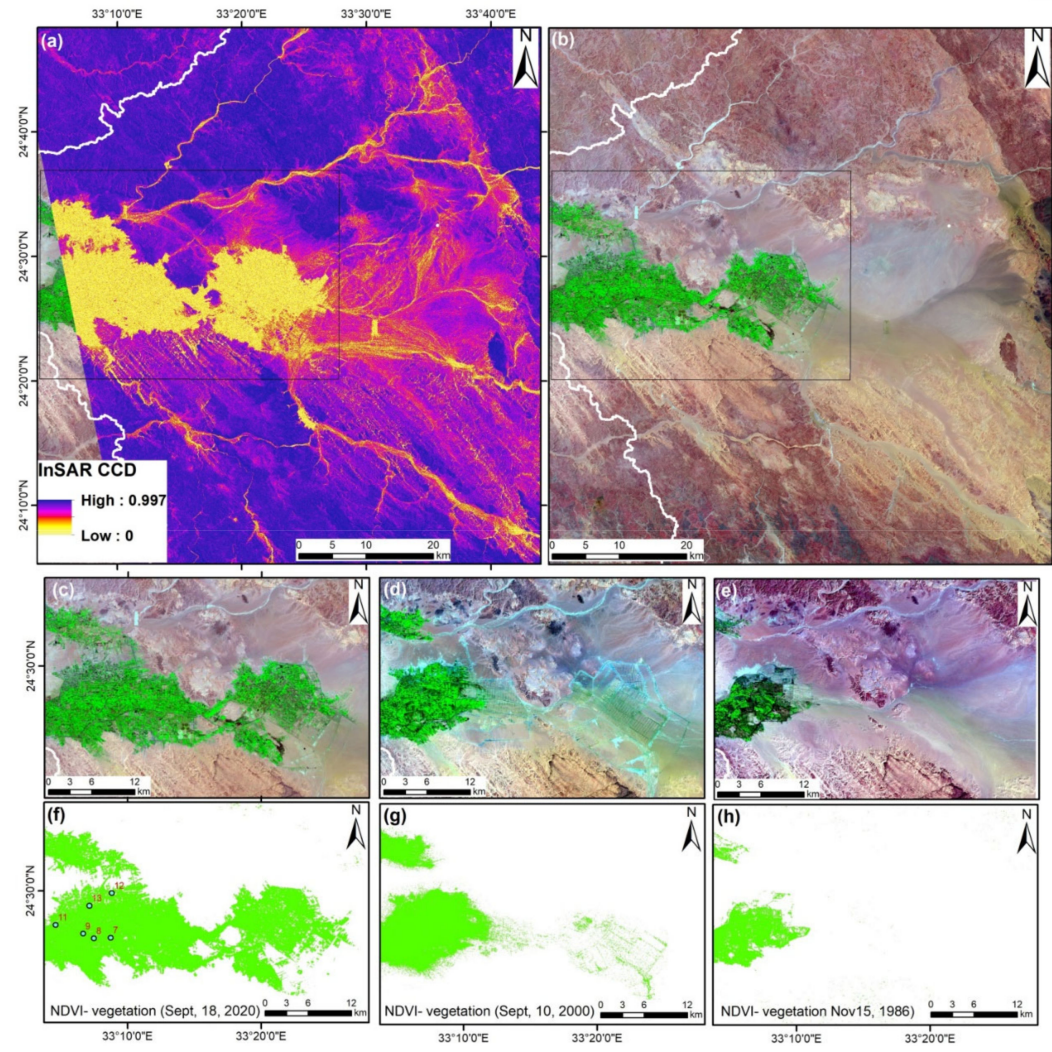

Figure 14. (a) InSAR CCD of the downstream area showing active streams in yellow and vegetation in comparison to Landsat-8 in (b); (c-e) Landsat images of years 2020, 2000, and 1986, respectively. (f-h) NDVI vegetation derived from Landsat images of years 2020, 2000, and 1986, respectively.

\section{Conclusions}

The integration of ALOS/PALSAR, Landsat-8, SRTM DEM, and TRMM data successfully characterized the geologic, geomorphic, structural, and hydrologic settings of the area east of Kom Ombo and potentially demarcated the groundwater. The present study successfully compiled geologic/geomorphic and hydrologic data for revealing the potential recharge zones. The evidential maps, namely, geology, lineaments, stream-networks, topography, slope, depressions, radar backscattered, rainfall data, seismicity, and morphometric data, were integrated through a GIS-based knowledge-driven approach to reveal GPZs. The resultant map revealed five potential groundwater zones that are very low $(6.56 \%)$, low $(22.62 \%)$, moderate $(30.75 \%)$, high $(29.71 \%)$, and very high $(10.34 \%)$. Such zones were verified by matching with agricultural activities depicted from satellite images, well data, and stream activities derived from the InSAR CCD images. Well data revealed that the obtained results will be beneficial for maintaining water supplies, groundwater abstraction, and understanding relationships between the surface water infiltrations in arid regions. The overall outcomes present the fact that combining different data sets derived from satellite sensors as well as geologic, structural, and hydrologic factors is a substantial tool for detecting geologic features and exploring groundwater in arid environments.

Author Contributions: M.A. conceived and designed the manuscript; M.A. collected, processed, and analyzed the data, and performed the proposed methods; M.A. and Q.Z. interpreted and discussed the results; M.A. wrote and M.A. and Q.Z. edited and revised the manuscript; M.A. handled the submission steps. All authors have read and agreed to the published version of the manuscript.

Funding: The first author has declared that this research was funded by "The National Key Research and Development Program of China, grant number 2017YFC0404503" and "National Natural Science foundation of China, grant number 41601529".

Institutional Review Board Statement: Not applicable. 
Informed Consent Statement: Not applicable.

Data Availability Statement: The data presented in this study are available on request from the corresponding author.

Acknowledgments: The authors are very grateful for the very helpful suggestions made by the editors and anonymous reviewers, which helped us to improve the manuscript. The authors would like to extend their sincere appreciation to the President and Vice President for Postgraduate and Research Affairs, South Valley University, Egypt. And we would like to thank I. S. Abdelsadek and S. Y. Mohamed for help and constructive comments.

Conflicts of Interest: The authors declare no conflict of interest.

\section{References}

1. Benjmel, K.; Amraoui, F.; Boutaleb, S.; Ouchchen, M.; Tahiri, A.; Touab, A. Mapping of Groundwater Potential Zones in Crystalline Terrain Using Remote Sensing, GIS Techniques, and Multicriteria Data Analysis (Case of the Ighrem Region, Western Anti-Atlas, Morocco). Water 2020, 12, 471. [CrossRef]

2. Abdelkareem, M.; El-Baz, F.; Askalany, M.; Akawy, A.; Ghoneim, E. Groundwater prospect map of Egypt's Qena Valley using data fusion. Int. J. Image Data Fusion 2012, 3, 169-189. [CrossRef]

3. Prabhakar, A.; Tiwari, H. Land use and land cover effect on groundwater storage. Model. Earth Syst. Environ. 2015, 1, 45. [CrossRef]

4. $\quad$ UNESCO. The United Nations World Water Development Report 2015: Water for a Sustainable World; UNESCO: Paris, France, 2015.

5. Mukherjee, I.; Singh, U.K. Delineation of groundwater potential zones in a drought-prone semi-arid region of east India using GIS and analytical hierarchical process techniques. CATENA 2020, 194, 104681. [CrossRef]

6. Achu, A.L.; Reghunath, R.; Thomas, J. Mapping of Groundwater Recharge Potential Zones and Identification of Suitable Site-Specific Recharge Mechanisms in a Tropical River Basin. Earth Syst. Environ 2020, 4, 131-145. [CrossRef]

7. Hussein, H.; Conker, A.; Grand, M. Small is beautiful but not trendy: Understanding the allure of big hydraulic works in the Euphrates-Tigris and Nile waterscapes. Mediterr. Politics 2020. [CrossRef]

8. Hussein, H. The Guarani Aquifer System, highly present but not high profile: A hydropolitical analysis of transboundary groundwater governance. Environ. Sci. Policy 2018, 83, 54-62. [CrossRef]

9. Abdelkareem, M.; El-Baz, F. Analyses of optical images and radar data reveal structural features and predict groundwater accumulations in the central Eastern Desert of Egypt. Arab. J. Geosci. 2015, 8, 2653-2666. [CrossRef]

10. Moubark, K.; Abdelkareem, M. Characterization and assessment of groundwater resources using hydrogeochemical analysis, GIS, and field data in southern Wadi Qena, Egypt. Arab. J. Geosci 2018, 11, 598. [CrossRef]

11. Gaber, A.; Abdelkareem, M.; Abdelsadek, I.S.; Koch, M.; El-Baz, F. Using InSAR coherence for investigating the interplay of fluvial and aeolian features in arid lands: Implications for groundwater potential in Egypt. Remote. Sens. 2018, 10, 832. [CrossRef]

12. Mallick, J.; Khan, R.A.; Ahmed, M.; Alqadhi, S.D.; Alsubih, M.; Falqi, I.; Hasan, M.A. Modeling groundwater potential zone in a semi-arid region of Aseer using fuzzy-AHP and geoinformation techniques. Water 2019, 11, 2656. [CrossRef]

13. Abdalla, F.; Moubark, K.; Abdelkareem, M. Groundwater potential mapping using GIS, linear weighted combination techniques and geochemical processes identification, west of the Qena area, Upper Egypt. J. Taibah Univ. Sci. 2020, 14, 1350-1362. [CrossRef]

14. Odeh, T.; Mohammad, A.H.; Hussein, H.; Ismail, M.; Almomani, T. Over-pumping of groundwater, northern Jordan: A conceptual model to analyze the effects of urbanization and agricultural activities on groundwater levels and salinity. Environ. Earth Sci. 2019, 78, 40. [CrossRef]

15. Avtar, R.; Singh, C.K.; Shashtri, S.; Singh, A.; Mukherjee, S. Identification and analysis of groundwater potential zones in KenBetwa river linking area using remote sensing and geographic information system. Geocarto Int. 2010, 25, 379-396. [CrossRef]

16. Murmu, P.; Kumar, M.; Lal, D.; Sonker, I.; Singh, S.K. Delineation of groundwater potential zones using geospatial techniques and analytical hierarchy process in Dumka district, Jharkhand, India. Groundw. Sustain. Dev 2019, 9, 100239. [CrossRef]

17. Çelik, R. Evaluation of Groundwater Potential by GIS-Based Multicriteria Decision Making as a Spatial Prediction Tool: Case Study in the Tigris River Batman-Hasankeyf Sub-Basin, Turkey. Water 2019, 11, 2630. [CrossRef]

18. Andualem, T.G.; Demeke, G.G. Groundwater potential assessment using GIS and remote sensing: A case study of Guna tana landscape, upper blue Nile Basin, Ethiopia. J. Hydrol. Reg. Stud. 2019, 24, 100610. [CrossRef]

19. Kumar, A.; Mondal, N.C.; Ahmed, S. Identification of Groundwater Potential Zones Using RS, GIS and AHP Techniques: A Case Study in a Part of Deccan Volcanic Province (DVP), Maharashtra, India. J. Indian Soc. Remote. Sens. 2020, 48, 497-511. [CrossRef]

20. Al-Djazouli, M.O.; Elmorabiti, K.; Rahimi, A.; Amellah, O.; Fadil, O.A.M. Delineating of groundwater potential zones based on remote sensing, GIS and analytical hierarchical process: A case of Waddai, eastern Chad. GeoJournal 2020. [CrossRef]

21. Berhanu, K.G.; Hatiye, S.D. Identification of Groundwater Potential Zones Using Proxy Data: Case study of Megech Watershed, Ethiopia. J. Hydrol. Reg. Stud. 2020, 28, 100676. [CrossRef]

22. Ghosh, D.; Mandal, M.; Banerjee, M.; Karmakar, M. Impact of hydro-geological environment on availability of groundwater using analytical hierarchy process (AHP) and geospatial techniques: A study from the upper Kangsabati river basin. Groundw. Sustain. Dev. 2020, 11, 100419. [CrossRef] 
23. Lentswe, G.B.; Lentswe, M. Delineation of potential groundwater recharge zones using analytic hierarchy process-guided GIS in the semi-arid Motloutse watershed, eastern Botswana. J. Hydrol. Reg. Stud. 2020, 28, 100674. [CrossRef]

24. Abdelkareem, M. Targeting flash flood potential areas using remotely sensed data and GIS techniques. Nat. Hazards 2017, 85, 19-37. [CrossRef]

25. Abdelkareem, M.; El-Baz, F. Remote sensing of paleodrainage systems west of the Nile River, Egypt. Geocarto Int. 2017, 32, 541-555. [CrossRef]

26. EGSMA. Geological Map of Egypt, Scale 1:2,000,000; The Egyptian Geological Survey and Mineral Authority: Cairo, Egypt, 1981.

27. Said, R. The Geology of Egypt; A.A. Balkema: Rotterdam, The Netherlands; Brookfield, VT, USA, $1990 ;$ p. 734.

28. Abdelkareem, M.; Abdalla, F.; Mohamed, S.Y.; El-Baz, F. Mapping paleohydrologic features in the arid areas of Saudi Arabia using remote-sensing data. Water 2020, 12, 417. [CrossRef]

29. Abdelkareem, M.; Bamousa, A.O.; Hamimi, Z.; Kamal El-Din, G.M. Multispectral and RADAR images integration for geologic, geomorphic, and structural investigation in southwestern Arabian Shield, Al Qunfudhah area, Saudi Arabia. J. Taibah Univ. Sci. 2020, 14, 383-401. [CrossRef]

30. O'Callaghan, J.F.; Mark, D.M. The extraction of drainage networks from digital elevation data. Comput. Vis. Graph. Image Process. 1984, 28, 323-344. [CrossRef]

31. Abdelkareem, M.; Gaber, A.; Abdalla, F.; El-Din, G.K. Use of optical and radar remote sensing satellites for identifying and monitoring active/inactive landforms in the driest desert in Saudi Arabia. Geomorphology 2020, 362, 107197. [CrossRef]

32. Havivi, S.; Amir, D.; Schvartzman, I.; August, Y.; Maman, S.; Rotman, S.R.; Blumberg, D.G. Mapping dune dynamics by InSAR coherence. Earth Surf. Process. Landf. 2018, 43, 1229-1240. [CrossRef]

33. Derauw, D. Phase unwrapping using coherence measurements. In Proceedings of the SPIE 2584, Synthetic Aperture Radar and Passive Microwave Sensing, Paris, France, 21 November 1995; pp. 319-324. [CrossRef]

34. Beumier, C.; Closson, D.; Lacroix, V.; Milisavljevic, N.; Yvinec, Y. Mine Action-The Research Experience of the Royal Military Academy of Belgium; InTechOpen: London, UK, 2017; p. 290.

35. Bonham-Carter, G.F. Geographic Information Systems for Geoscientists: Modelling with GIS; Pergamon Press: Oxford, UK, $1994 ;$ p. 398.

36. Carranza, E.J.M. Geochemical Anomaly and Mineral Prospectivity Mapping in GIS; Elsevier B.V: Amsterdam, The Netherlands, 2008.

37. Voogd, J.H. Multicriteria Evaluation for Urban and Regional Planning. Ph.D. Thesis, Delftsche Uitgevers Maatschappij, Delft, The Netherlands, 1982. [CrossRef]

38. Selvarani, A.G.; Maheswaran, G.; Elangovan, K. Identification of Artificial Recharge Sites for Noyyal River Basin Using GIS and Remote Sensing. J. Indian Soc. Remote Sens. 2017, 45, 67-77. [CrossRef]

39. Yeh, H.-F.; Cheng, Y.-S.; Lin, H.-I.; Lee, C.-H. Mapping groundwater recharge potential zone using a GIS approach in Hualian River, Taiwan. Sustain. Environ. Res. 2016, 26, 33-43. [CrossRef]

40. Pande, C.B.; Khadri, S.F.R.; Moharir, K.N.; Patode, R.S. Assessment of groundwater potential zonation of Mahesh River basin Akola and Buldhana districts, Maharashtra, India using remote sensing and GIS techniques. Sustain. Water Resour. Manag. 2018, 4, 965-979. [CrossRef]

41. Doctor, D.H.; Young, J.A. An evaluation of automated GIS tools for delineating karst sinkholes and closed depressions from 1-meter LIDAR-derived digital elevation data. In Proceedings of the 13th Multidisciplinary Conference on Sinkholes and the Engineering \& Environmental Impacts of Karst, Carslbad, NM, USA, 6-10 May 2013.

42. Magesh, N.S.; Chandrasekar, N.; Soundranayagam, J.P. Delineation of groundwater potential zones in Theni district, Tamil Nadu, using remote sensing, GIS and MIF techniques. Geosci. Front. 2012, 3, 189-196. [CrossRef]

43. Abdelkareem, M. Space Data and GIS Applications for Arid Region; South Valley University: Wadi Qena, Egypt, $2012 ;$ p. 251.

44. El Bastawesy, M.; Faid, A.; Gammal, E.S.E. The Quaternary development of tributary channels to the Nile River at Kom Ombo area, Eastern Desert of Egypt, and their implication for groundwater resources. Hydrol. Process. 2010, 24, 1856-1865. [CrossRef]

45. Zebker, H.A.; Rosen, P.; Hensley, S.; Mouginis-Mark, P.J. Analysis of active lava flows on Kilauea volcano, Hawaii, using SIR-C radar correlation measurements. Geology 1996, 24, 495-498. [CrossRef]

46. Abdelsalam, M.G.; Stern, R.J.; Berhane, W.G. Mapping gossans in arid regions with Landsat TM and SIR-C images: The Beddaho Alteration Zone in northern Eritrea. J. Afr. Earth Sci. 2000, 30, 903-916. [CrossRef]

47. Al-Ruzouq, R.; Shanableh, A.; Yilmaz, A.G.; Idris, A.; Mukherjee, S.; Khalil, M.A.; Gibril, M.B.A. Dam Site Suitability Mapping and Analysis Using an Integrated GIS and Machine Learning Approach. Water 2019, 11, 1880. [CrossRef]

48. Caine, J.S.; Forster, C.B. Fault Zone Architecture and Fluid Flow: Insights from Field Data and Numerical Modeling. In Faults and Subsurface Fluid Flow in the Shallow Crust. Geophysical Monograph 113; Haneberg, W.C., Mozley, P.S., Moore, J.C., Goodwin, L.B., Eds.; American Geophysical Union: Washington, DC, USA, 1999; pp. 101-127.

49. Apaydin, A. Relation of tectonic structure to groundwater flow in the Beypazari region, NW Anatolia, Turkey. Hydrogeol. J. 2010, 18, 1343-1356. [CrossRef]

50. Ganapuram, S.; Kumar, G.T.V.; Krishna, I.V.M.; Kahya, E.; Demirel, M.C. Mapping of groundwater potential zones in the Musi basin using remote sensing data and GIS. Adv. Eng. Softw. 2009, 40, 506-518.

51. Sibson, R.H.; Rowland, J.V. Stress, fluid pressure and structural permeability in seismogenic crust, North Island, New Zealand. Geophys. J. Int. 2003, 154, 584-594. [CrossRef]

52. Manga, M.; Beresnev, I.; Brodsky, E.E.; Elkhoury, J.E.; Elsworth, D.; Ingebritsen, S.E.; Mays, D.C.; Wang, C.-Y. Changes in permeability caused by transient stresses: Field observations, experiments, and mechanisms. Rev. Geophys. 2012, 50. [CrossRef] 
53. Mastrorillo, L.; Saroli, M.; Viaroli, S.; Banzato, F.; Valigi, D.; Petitta, M. Sustained post-seismic effects on groundwater flow in fractured carbonate aquifers in Central Italy. Hydrol. Process. 2020, 34, 1167-1181. [CrossRef]

54. Wang, C.-Y.; Manga, M. New streams and springs after the 2014 Mw6.0 South Napa earthquake. Nat. Commun. 2015, 6, 7597. [CrossRef] [PubMed]

55. Conoco, Geological Map of Egypt, Scale 1:500,000; The Egyptian General Petroleum Corporation: Cairo, Egypt, 1987.

56. Emara, M.M.; El-Sabbah, M.M.B.; Gomaa, M.A.; Mohallel, S.A. Remarks on the Hydrogeochemistry of the Area Between Idfu and Aswan, Eastern Desert, Egypt. Aust. J. Basic Appl. Sci. 2012, 6, 483-496.

57. Sandford, K.S. The Pliocene and Pleistocene Deposits of Wadi Qena and of the Nile Valley between Luxor and Assiut (QAU). Q. J. Geol. Soc. 1929, 85, 493-548. [CrossRef]

58. Butzer, K.W.; Hansen, C.L. Desert and River in Nubia: Geomorphology and Prehistoric Environments at the Aswan Reservoir; University of Wisconsin Press: Madison, WI, USA, 1968; p. 562.

59. Abdelkareem, M.; El-Baz, F. Evidence of drainage reversal in the NE Sahara revealed by space-borne remote sensing data. J. Afr. Earth Sci. 2015, 110, 245-257. [CrossRef]

60. Abdelkareem, M.; Ghoneim, E.; El-Baz, F.; Askalany, M. New insight on paleoriver development in the Nile basin of the eastern Sahara. J. Afr. Earth Sci. 2012, 62, 35-40. [CrossRef]

61. El-Baz, F. Sand accumulation and groundwater in the eastern Sahara. Int. Union of Geol. Sci. 1998, 21, 147-151. [CrossRef]

62. Abdel Kreem, W.F.M. Chemical and Isotopic Investigation of Groundwater Aquifers in Idfu Region on the Fringes of Qena Governorate. Master's Thesis, Cairo University, Cairo, Egypt, 2000; p. 137.

63. Cammeraat, L.H.; Imeson, A.C. The evolution and significance of soil-vegetation patterns following land abandonment and fire in Spain. CATENA 1999, 37, 107-127. [CrossRef]

64. Owuor, S.O.; Butterbach-Bahl, K.; Guzha, A.C.; Rufino, M.C.; Pelster, D.E.; Díaz-Pinés, E.; Breuer, L. Groundwater recharge rates and surface runoff response to land use and land cover changes in semi-arid environments. Ecol. Process. 2016, 5, 16. [CrossRef] 